\title{
A Value-Impact Assessment of Alternate Containment Concepts
}

David D. Carlson, Jack W. Hickman

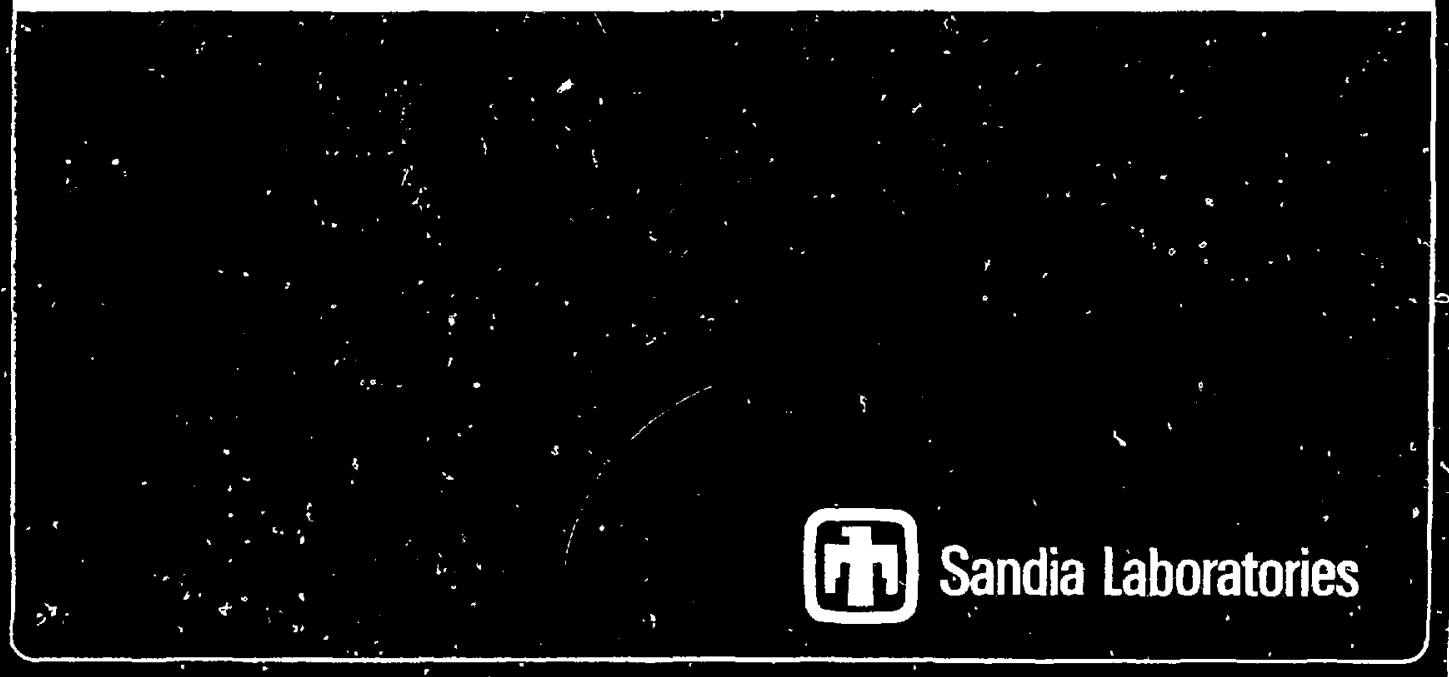

Preparod for

U. S. NIICLEAR REGULATORY COMMISSION 
Monuscript Sulmitted: April 10, $1: 79$

IJate fublished: lunc 1!7!"

Sitn:lia laboratories Alhuque rọte, Sx 87185 opeanded be

Situdia conpulation for the

U. S. Department w linewer

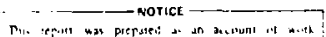

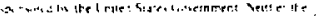

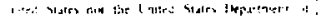

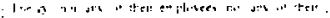

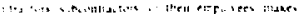

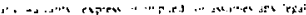
A

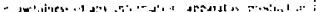

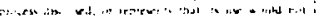

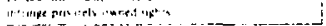

\section{I'repared for}

Division or Reactor Safety Researich Orfice of Nuclear Regulatory Research U. S. Nuclear Regulatory Comnission Washington, DC 20555

Under Interagency $\Lambda$ greement DOE 40-550-75 NRC FIN No, $\Lambda-1027$ 


\section{ACKNOWLEDGMENTS}

The authors wish ta acknowledge the contributions of the following people to this study:

J. A. Milloy, Sandia Laboratories, for engineering insights;

W. B. Murfin, P. W. Conrad, and L. D. Buxton of Sandia Laboratories for phenomenological insights;

M. A. Taylor, U. S, Nuclear Regulatory Commission, for probabilistic and Reactor Safety Study insights; and

A. W. Frazier, Sandia Laboratories, for computational assistance. 


\begin{abstract}
A value-impact assessment is made of alternate containment concepts for commercial light water reactor power plants. Several alternate containment concepts are evaluated and compared considering their potential for reducing public risk and their construction cost. The results and methodology of the Reactor Safety Study (WASH-1400) are used as a basis for determining potential risk reductions that could be realized by alternate containment designs. Among the alternatives considered, filtered atmosphe ric venting appears to offer the greatest potential for reducing public risk for the least impact.
\end{abstract}




\section{CONTENTS}

EXECUTIVE SUMMARY

CHAPTER I. INTRODUCTION

11

CHAPTER II. CONTAINMENT FAILURE MONES

CHAPTER III. ALTERNATE CONTATNMANT CONCEPTS AND DESIGNS 21

Alternate Containment Concepts $\quad 21$

Containment Besign Alternatives $\quad 22$

ChAPTER IV. DESIGN ALTERNATIVE DESCRIPTIONS

Stronger Containment $\quad 25$

Shallow Underground Siting 2 is

Deep Underground Siting 26

$\begin{array}{ll}\text { Increased Containment Volume } & 27\end{array}$

Filtered Atmospheric Venting $\quad 28$

Compartment Venting $\quad 28$

Thinned Base Mat 30

Evacuated Containment $\quad 30$

Double Containment $\quad 30$

CHAPTER V. VALUE ASSESSMENT

Flltered Atmospheric Venting

Compartment Venting 33

Deep Underground Siting $\quad 34$

Stronger Containment $\quad 35$

Increased Containment $\quad 35$

Shallow Underground Siting $\quad 36$

Evacuated Containment $\quad 36$

Double Containment $\quad 37$

Thinned Base Mat 38

Complementary Cumulative Distribution Functions $\quad 40$

$\begin{array}{ll}\text { CHAPTER VI. IMPACT ASSESSMENT } & 42\end{array}$

Filtered Atmospheric Venting $\quad 42$

Compartment Venting $\quad 42$

Deep Underground Siting

Stronger Containment

Increaged Contalnment Volume $\quad 44$

Shallow Underground Siting $\quad 44$ 


\section{CONTENTS (Cont'd)}

Evacuater Containment

Double Containment

\section{ILLISTRRATIONS}

\begin{tabular}{|c|c|c|}
\hline Figure & & Page \\
\hline 1 & Relative Importance of Containment Failure Modes & 213 \\
\hline 2 & Relative Contributions to Containinent Failur a Pressure & $3 !$ \\
\hline 3 & Stronger Containment & $2: j$ \\
\hline 4 & Shallow Underground Siting & 26 \\
\hline 5 & Deep Underground Siting & 27 \\
\hline G & Increasied Containment Volume & 28 \\
\hline 7 & Filtered Atmospheric Venting & 29 \\
\hline 8 & Compartment Venting & 29 \\
\hline 9 & Thinned Base Mat & 30 \\
\hline 10 & Evacuated Containment & 31 \\
\hline 11 & Double Containment & 31 \\
\hline 12 & Probability Distribution for Early Fatalities per Reactor Year & 41 \\
\hline 13 & Probability Distribution for Latent Cancer I'atalities per Reactor Year & 41 \\
\hline 14 & Qualitetive Value-Impact Matrix & 47 \\
\hline
\end{tabular}

TABLES

II PWR Dominant Accident Sequences vs Release Categories

III BWR Dominant Accident Sequences of Each Event Tree vs Release Category

IV Contribution of Containment Failure Modes to Each Release Category - PWR 
XII Expected Values of Risk for Compirtment Fenting

XIII Expected Values of Risk for Neep Underground Siting

XIV Expected Values of Risk for Stronger Containment

XV Expected Values of Risk for Increased Containment Volume

XVI Expected Values of Rlsk for Shallow Underground Siting

XVII Expected Values of Risk for Evacuated Containment

XVIII Expected Values of Risk for Duuble Containment

XIX Expected Values of Risk for Thinned Base Mat

XX Relative Risk for Altemative Containment Designs Normalized to Current Surface Plants

XXI Potential Impacts of Alternite Designs 
This study was performed by Sandia Laboratories at the request of the Office of Nuclear Regulatory Research of the Nuclear Regulatory Commission. The study was done to support a briefing given to the Commission on alternate containment concepts. It was requested that the briefing include concepts "between the present regulations and underground siting that can add to plant safety." The study was performed in a six-week period between Aprî 15, and May 20, 1977. The Commission briefing was given on July $?, 1977$.

To complete the study, the relative importance of containment failure modes was determined. It was found that overpressure failure of the containment due to steam and noncondensable gases generated during a core-meltdown accident was the principal contributor to risk. Nine design alternatives reflecting six fundamental concepts for inhibiting overpressure failures were evaluated with potentlal risk reduction as the figure of merit for assessing relative value. Although combinations of altermatives could have been considered, the objective of the study was to evaluate each alternative on its own merits rather than to identify an optimal design comhination. For each alternative, construction costs and impacts on safety and normal plant operations were identified. The results are presented in the form of a qualitative value-impact matrix (see Figure 14). Filtered Atmospheric Venting was judged most favorable based on the value-impact comparison.

To place the results of this study in proper perspective, several points need to be made. The results of this study are based principally on insights from the Reactor Safety Study, which itself evaluated only two nuclear power plants. Although an effort was made to eliminate considerations reflecting atypical characteristics of these plants, the resulis of this value-impact assessment must be considered as only indicative of what a much broader study would find. The design alternatives considered herein were judged to be practical, but their feasibility has not been demonstrated. The reductions in relative risk calculated in the study should be considered as only potential gains since other factors which were not dominant in the Reactor Safety Study and therefore, not given detalled consideration, become more important and perhaps could dominate the risk, And finally, this study did not address the broader question of whether any altemate contalnment design is desirable or justified.

The atudy was intended to Identify the logical altemattves and, among those, to highlight the ones whlch appear most promising on a value-impact scale.

* Reactor Safety Study, An Assessment of Accident Rlske in U.S. Commerclal Reactor Pawer Plante, U,S. Nuclear Regulatory Commission, WASH-1400 (NUREG 75/014) October 19075. 


\section{A VALUE-IMPACT A JSESSMENT OF ALTERNATE \\ CONTA NNENT CONCEPTS}

\section{CIIAPTER I, INTRODUCTION}

In April 1977, the Nuclear Regulatory Commission requested that Sandla Laboratories perform a value-impact assessment of alternate contuinment concepts between present designs and uncierground siting that could add to plant safety. The study was completed in the six-week period between April 15 and May 30, 1977. The results were presented to the Commission in a public meeting on July 7,1977 .

The study was performed in five steps. They were:

1. Determination of the relative importance of containment failure modes,

2. Development of alternate containment concents,

3. Formulation of design alternatives,

4. Determination of potential value, and

5. Determination of potential impact.

This study used many of the data, methods, and insights from the Reactor Safety Study. An analysis of dominant accident sequencis and containment fallure modes formed the basis for estimating the risk for each alternate containment concept considered. The Reactor Safety Study determined that acidents which could result in core-meltdown were the major contributors to public risk. The riak associated with the Reactor Safety Study plants is dominated by the few highest probability sequences in the high consequence release categories. The same accident sequances were used in this study; thus, only a few sequences were considered in detail. Given that an accident sequence occur's, the Reactor Saiety Study analysis indicated that the resulting level of consequences is dependent upon the mode of containment failure. This provides important insight into the potential for reducing risk to the publtc. Those al te rnate containment concepts which most reduce the likelihood of containment failures leading to high consequence releases will be the most effectlve concepts for reducing public rosk. 
The inst step in the value-impact assessment was to determine the containment failure modes which made the greatest contributions to public risk. The Reactor Safety Study identified five potential containment failure modes for pressurized water reactors (PWRs) and nine for boiling water reactors (BWRs). They are shown in Table $I$. To identify those altemate containment concepts which have the rnns: potential for reducing public risk and to evaluate the risk reduction realized, the risks associated with accidents breaching containment in each fallure mode were calculated, and the relative impurtance of each containment failure mode to risk was determined.

\section{TABI_E I}

Containment I'ailure Modes

\section{PWR}

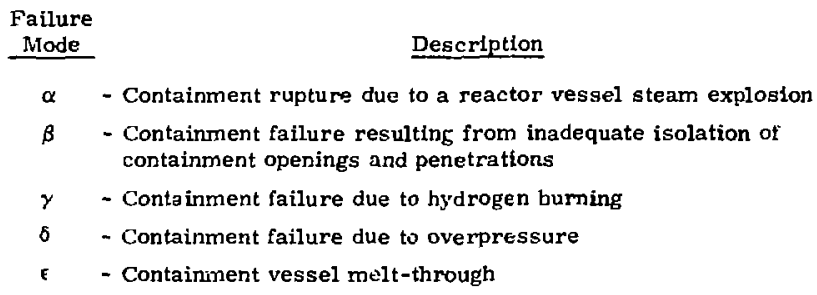

$\underline{\text { BWR }}$

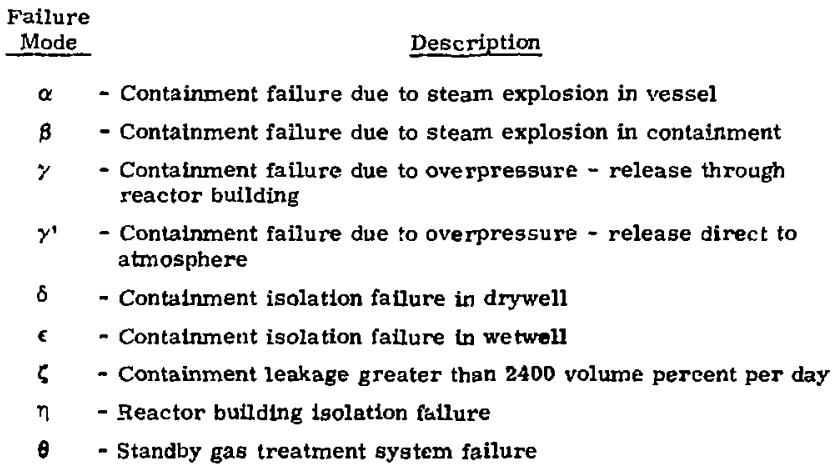


The Reactor Safery Study determined a set of dominant accident sequences for both PWRs and BWRs. These were categorized into several release categories, nine categories for the PWR and five categories for the BWR. The categories reflect differing severities of consequences resulting from the accident. The categories and dominant accident sequences are shown in Tables II and III. This study considered the same accident sequences and release categories, but differed slightly from the Reactor Safety Study in that the total probability of each release category was calculated by summing the probabilities of the accident sequences within each category rather than obtaining the total probability by using a Monte Carlo technique. To account for the possibility of an accident having different consequences than those of its assigned release cate ${ }^{*}$ ry, both the Reactor Safety Study and this study assumed a 10 percent chance of the accident being in the next higher or lower release category and a 1 percent chance of its being two release categories more or less severe. The contribution of each containment failure mode to the total probability of each release category was calculated and is shown in Tables $I V$ and $V$.

The expected consequences in terms of early fatalities, latent cancer fatalities, and property damage given that a release occurs were obtained using the consequence model from the Reactor Safety Study. The consequences were calculated for a site whose characteristics correspond to a composite of the reactors located in northeastern U. S. river valleys. The Reacto- Safety Study evacuation model was employed for all core melt accidents using an evacuation speed of 1.2 mph. The expected congequences per release for each category are given in Table VI.

The expected value of risk was calculated as follows:

$$
\sum_{i} P\left(c_{i}\right) C_{i}=\text { expected risk }
$$

where

$$
\begin{aligned}
P\left(c_{i}\right) & =\text { probabllity of release category } i \\
C_{i} & =\text { expected consequences given release in category } i \\
i & =\text { release category }(i=1,2,3, \ldots 9 \text { for } P W R ; \\
i & =1,2,3, \ldots 5 \text { for BWR })
\end{aligned}
$$

The expected value of the risk for each containment failure mode was calculated using the informstion contatned in Tables $\Gamma V, V$, and VI. The results of the calculation are given in Table VII and are shown graphically in Figure 1. 
TABLE $\mathbf{I}$

FWR Dominant Accldent Sequences

rB. Release Categories

\begin{tabular}{|c|c|c|c|c|c|c|c|c|c|}
\hline & \multicolumn{5}{|c|}{ mines cantomis } & \multicolumn{2}{|r|}{ core was } & \multicolumn{2}{|c|}{ more coll } \\
\hline & 4 & , & 1 & 4 & 3 & 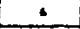 & 1 & $\bullet$ & $?$ \\
\hline apen & 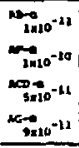 & 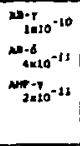 & 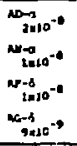 & $=0$ & 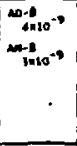 & 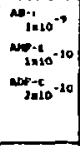 & 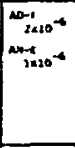 & ${ }_{i=10^{-1}}$ & $\sqrt{4} 1020^{-4}$ \\
\hline 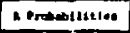 & $2 \times 10^{-7}$ & $\ln 10^{-6}$ & $1 \times 10^{-7}$ & $\ln 10^{-6}$ & $0.10^{-6}$ & $1 \times 10^{-7}$ & $1=10^{-6}$ & $1=30^{-5}$ & 2013 \\
\hline mane we & 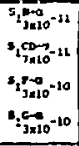 & 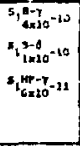 & 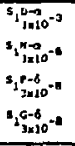 & 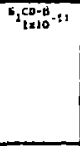 & 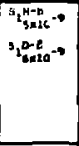 & 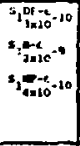 & 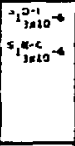 & $\sqrt{5,-5}{ }^{-5} \times 10^{-4}$ & $23010^{-4}$ \\
\hline 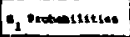 & $3030^{-4}$ & $2010^{-0}$ & $2 \times 20^{-7}$ & $3=10^{-1}$ & $2 \times 10^{-4}$ & $4=10^{-3}$ & $6.10^{-6}$ & $1010^{-5}$ & $=10^{-10}$ \\
\hline$s_{1}$ & 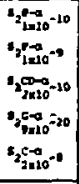 & 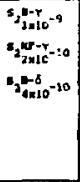 & 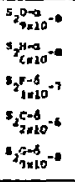 & $5, \infty 12010^{-12}$ & 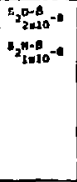 & 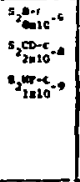 & 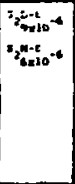 & & \\
\hline 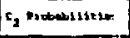 & $2 \times 20^{* 1}$ & $7=10^{-7}$ & $3 \times 10^{-6}$ & $1010^{-7}$ & $2010^{-7}$ & $3 \times 20^{\circ}$ & $2 \pi 60^{-3}$ & & \\
\hline moctom vessi & 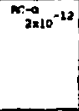 & 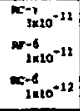 & ${ }_{1 \times 10^{-9}}^{n-3}$ & & & & ${ }_{3 n-6}^{n-6}$ & & \\
\hline I Proteblitities & $2 \times 10^{+11}$ & $1=10^{-10}$ & $2=10^{-9}$ & $7=15^{-10}$ & $1010^{-9}$ & $1=10^{-8}$ & $\ln 10^{-1}$ & & \\
\hline 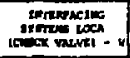 & & ${ }_{4 \rightarrow 10^{-6}}$ & & & & & & & \\
\hline Y Itodiltios & $1010^{-1}$ & $=010^{-6}$ & $4 \times 10^{-7}$ & $9 \times 10^{-6}$ & & & & & \\
\hline T) & מים & 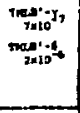 & 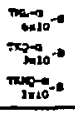 & & $\prod_{n=10^{2}}^{m-5} \cdot 10$ & $\sin _{6 \times 10}=1$ & 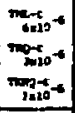 & & \\
\hline I nmomenesticos & $2 \pi 10^{-7}$ & $3 \times 10^{-6}$ & $4 \times 10^{-7}$ & $9 \times 10^{-8}$ & $2 \times 30^{\circ}$ & $2 \times 10^{-6}$ & $2+10^{-3}$ & & \\
\hline & & (t) sumit & or & . & $x$ ow ane & se chtrwalr & & & \\
\hline ran & $2010^{-7}$ & $\operatorname{lomet}$ & $0.10^{-6}$ & $5010^{-1}$ & "1010" & $c=10^{-6}$ & $4010^{-5}$ & $6010^{-3}$ & $\cos ^{\circ}$ \\
\hline ist nutis & $\$ 0100$ & $0100^{\circ 1}$ & $9.10^{-7}$ & $\ln 10^{-1}$ & $2110^{-7}$ & $2=10^{-6}$ & $=10^{-5}$ & $410^{\circ 6}$ & $\omega^{-3}$ \\
\hline itis enesis & $\mathrm{men}^{-4}$ & $1010^{-5}$ & $4 \times 12^{-5}$ & $9 \times 10^{-6}$ & $-10^{-4}$ & Je10 -5 & $n=10^{-1}$ & $=10^{\circ}$ & $\ln ^{-2}$ \\
\hline
\end{tabular}

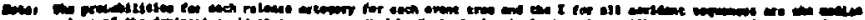

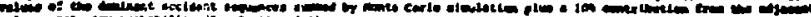

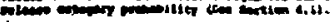


TABLE III

BWR Dominant Accident Sequences of Each Event Tree vs. Release Category"

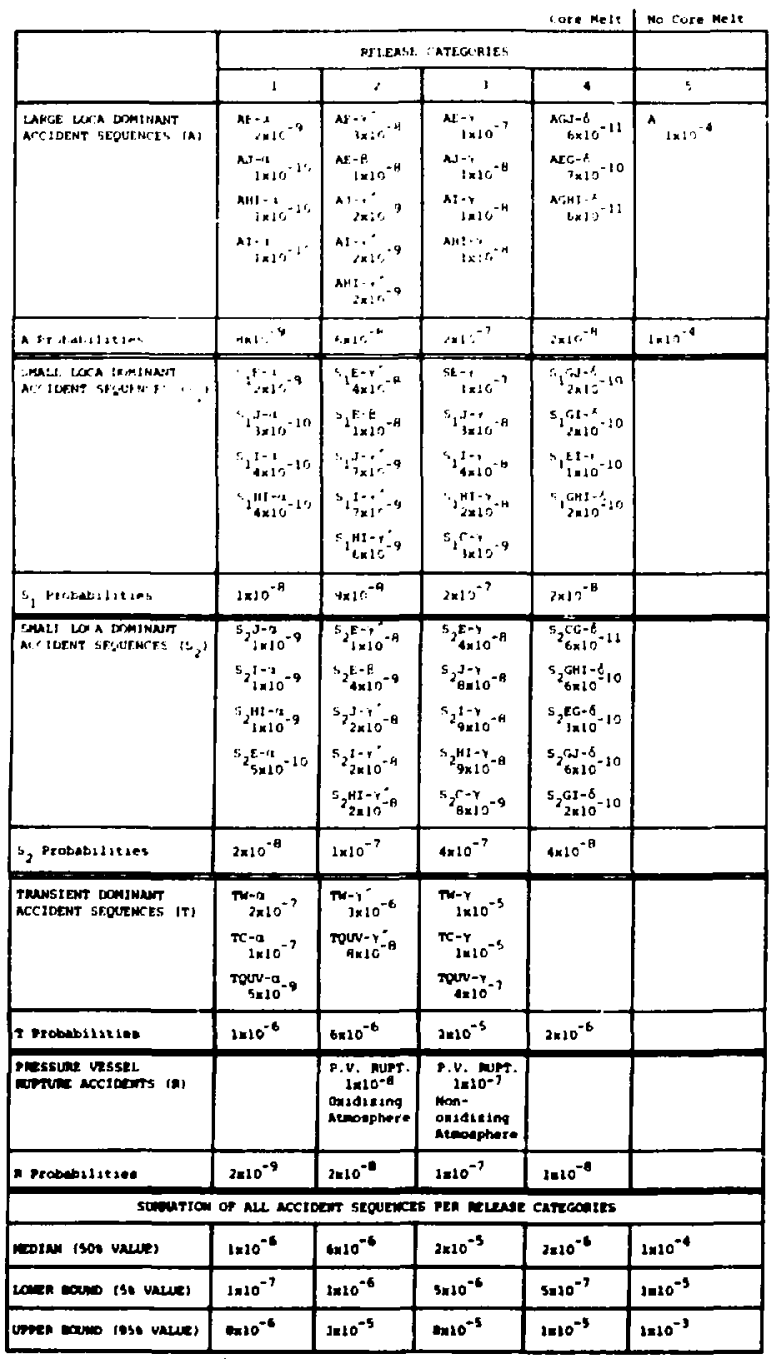

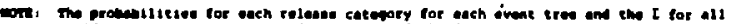

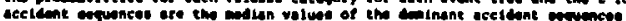

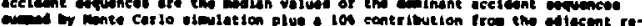

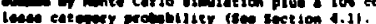

- Heactor Safaty Study, Appendix V. Table V 3-18 
TABLE IV

Contribution of Containment Failure Modes to Each Release Category - PWR

\begin{tabular}{|c|c|c|c|c|c|c|c|c|}
\hline $\begin{array}{c}\text { Release } \\
\text { Category }\end{array}$ & $\begin{array}{c}\text { Total } \\
\text { Probability }\end{array}$ & $\alpha$ & $\beta$ & $y$ & $\delta$ & $\varepsilon$ & $\mathrm{V} *$ & $\begin{array}{c}\text { Category } \\
9 * * * \\
\end{array}$ \\
\hline 1 & $7.5 \times 10^{-7}$ & $5.6 \times 10^{-8}$ & 0 & $7.0 \times 10^{-8}$ & $2.2 \times 10^{-7}$ & 0 & $4 \times 10^{-7}$ & 0 \\
\hline 2 & $6.9 \times 10^{-6}$ & $3.9 \times 10^{-8}$ & $\sim 0$ & $7.0 \times 10^{-7}$ & $2.2 \times 10^{-6}$ & 0 & $4 \times 10^{-6}$ & 0 \\
\hline 3 & $3.3 \times 10^{-6}$ & $3.4 \times 10^{-7}$ & $\sim 0$ & $7.0 \times 10^{-8}$ & $2.5 \times 10^{-6}$ & 0 & $4 \times 10^{-7}$ & 0 \\
\hline 4 & $3.4 \times 10^{-7}$ & $3.4 \times 10^{-8}$ & $4.9 \times 10^{-9}$ & $7.0 \times 10^{-9}$ & $2.5 \times 10^{-7}$ & $6.3 \times 10^{-9}$ & $4 \times 10^{-8}$ & 0 \\
\hline 5 & $4.8 \times 10^{-7}$ & $3.4 \times 10^{-9}$ & $4.9 \times 10^{-8}$ & 0 & $2.3 \times 10^{-8}$ & $4.0 \times 10^{-7}$ & 0 & 0 \\
\hline 6 & $4.0 \times 10^{-6}$ & 0 & $1.3 \times 10^{-8}$ & 0 & 0 & $4.0 \times 10^{-6}$ & 0 & 0 \\
\hline 7 & $3.8 \times 10^{-5}$ & 0 & $8.0 \times 10^{-8}$ & 0 & 0 & $3.4 \times 10^{-5}$ & 0 & $4 \times 10^{-6}$ \\
\hline 8 & $4.4 \times 10^{-5}$ & 0 & $8.0 \times 10^{-7}$ & 0 & 0 & $3.4 \times 10^{-6}$ & 0 & $4 \times 10^{-5}$ \\
\hline 9 & $4.0 \times 10^{-4}$ & 0 & $8.0 \times 10^{-8}$ & 0 & 0 & $3.4 \times 10^{-7}$ & 0 & $4 \times 10^{-4}$ \\
\hline
\end{tabular}

* Check valve rupture in low pressure injection system resulting in a LOCA outside containment without an associated containment failure mode.

** Non-core melt accident with no containment failure. 
TABLE V

Contribution of Containment Failure Modes to Each Release Category - BWR

\begin{tabular}{|c|c|c|c|c|c|c|c|c|}
\hline $\begin{array}{c}\text { Release } \\
\text { Category }\end{array}$ & $\begin{array}{c}\text { Total } \\
\text { Probability }\end{array}$ & $\alpha$ & $\beta$ & $\gamma$ & $\gamma^{\prime}$ & $\delta$ & $\epsilon$ & $\begin{array}{c}\text { Category } \\
5 * \\
\end{array}$ \\
\hline 1 & $8,5 \times 10^{-7}$ & $3.1 \times 10^{-7}$ & $2,4 \times 10^{-9}$ & $2.1 \times 10^{-7}$ & $3.3 \times 10^{-7}$ & 0 & 0 & 0 \\
\hline 2 & $5.5 \times 10^{-6}$ & $3,1 \times 10^{-8}$ & $2.4 \times 10^{-8}$ & $2.1 \times 10^{-6}$ & $3.3 \times 10^{-6}$ & $\sim 0$ & 0 & 0 \\
\hline 3 & $2.2 \times 10^{-5}$ & $3.1 \times 10^{-9}$ & $2.4 \times 10^{-9}$ & $2.1 \times 10^{-5}$ & $3.3 \times 10^{-7}$ & $\sim 0$ & 0 & $1 \times 10^{-6}$ \\
\hline 4 & $1.2 \times 10^{-5}$ & 0 & 0 & $2.1 \times 10^{-6}$ & $3.3 \times 10^{-8}$ & $3.2 \times 10^{-9}$ & 0 & $1 \times 10^{-5}$ \\
\hline 5 & $1.0 \times 10^{-4}$ & 0 & 0 & $2.1 \times 10^{-7}$ & 0 & $\sim 0$ & 0 & $1 \times 10^{-4}$ \\
\hline
\end{tabular}

Other containment failure modes did not contribute significantly.

*Non-core melt accident with no containment fallure. 
TABLE VI

Expected Consequences per Release Northeast River Valley Composite Site

$\underline{\text { PWR }}$

\begin{tabular}{|c|c|c|c|}
\hline Category & $\begin{array}{c}\text { Early } \\
\text { Fatalities } \\
\end{array}$ & $\begin{array}{c}\text { Latent } \\
\text { Cancer Fatalities }\end{array}$ & $\begin{array}{c}\text { Property Damage } \\
\left(10^{6} \mathrm{\$}\right) \\
\end{array}$ \\
\hline 1a (cold) & 91 & 120 & 2050 \\
\hline 1b (hot) & 8 & 114 & 2270 \\
\hline 2 & 7 & 67 & 2440 \\
\hline 3 & 0.4 & 55 & 987 \\
\hline 4 & 0 & 18 & 335 \\
\hline 5 & 0 & 6 & 201 \\
\hline 6 & 0 & 1 & 173 \\
\hline 7 & 0 & $\sim 0$ & 171 \\
\hline 8 & 0 & $\sim 0$ & 1 \\
\hline$y$ & 0 & $\sim 0$ & 0 \\
\hline \multicolumn{4}{|l|}{ BWR } \\
\hline 1 & 7 & 154 & 2450 \\
\hline 2 & $\sim 1$ & 100 & 2070 \\
\hline 3 & 0 & 51 & 789 \\
\hline 4 & 0 & 3 & 29 \\
\hline 5 & 0 & $\sim 0$ & $\sim 0$ \\
\hline
\end{tabular}

The check valve rupture (V) sequence and overpressure failures $(\delta)$ dominate the risk in the PWR with hydrogen burning $(\gamma)$ and vessel steam explosions $(\alpha)$ contributing a minor portion. For the BWR, overpressure fallures $\left(\gamma\right.$ and $\left.\gamma^{\prime}\right)$ dominate the risk with vessel steam explosions contributing a secondary amount, Melt-through fallure contributes significantly to the property damage rlak for the PWR; this is a result of the evacuation model used. The cost consists almost totally of the cost of evacuation and emergency relocation of the evacuees, assumed for all core-melt accidents.

The check valve rupture sequence identified in the Reactor Safety Study involved failure of two check valves in the low pressure injection lines resulting in a loss-of-coolant accident outside of the containment. The large contrlbution of thls sequence to risk may well be atyplcal of most PWR日. In addition, It was belleved that regulatory action since the RSS resulted in a decreased 1tkellhood of such an eccident. Thus, the containment fallure mode consldered to be the dominant contributor to rlak for both PWRe and BWRs in thls atudy is overpreseure fatlure. It was concluded, therefore, that alternate contalnment designs that moat effectively inhlbit contalnment fallure due to overpressure should most effectively reduce publlc risk. 


\section{TABLE VIJ}

Contributions of Contairment Failure Modes to Expected Risks

PWR

\begin{tabular}{|c|c|c|c|}
\hline $\begin{array}{c}\text { Containment } \\
\text { Fallure Modes } \\
\end{array}$ & $\begin{array}{c}\text { Early } \\
\text { Fatalities/Yr } \\
\end{array}$ & $\begin{array}{c}\text { Latent Cancer } \\
\text { Fatalities } / \mathrm{Yr}_{\mathrm{r}} / \mathrm{Y}_{\mathrm{r}} \\
\end{array}$ & $\begin{array}{c}\text { Property } \\
\text { Damage/Yr }\end{array}$ \\
\hline$v$ & $4.6 \times 10^{-5}$ & $3.4 \times 10^{-4}$ & $11.0 \mathrm{~K}$ \\
\hline$\delta$ & $2.6 \times 10^{-5}$ & $3.2 \times 10^{-4}$ & $8.4 \mathrm{~K}$ \\
\hline$\gamma$ & $8.1 \times 10^{-6}$ & $5.9 \times 10^{-5}$ & $1.9 \mathrm{~K}$ \\
\hline$\alpha$ & $2.9 \times 10^{-6}$ & $2.8 \times 10^{-5}$ & $0.6 \mathrm{~K}$ \\
\hline$\epsilon$ & 0 & $6.5 \times 10^{-6}$ & $6.6 K$ \\
\hline$\beta$ & $\sim 0$ & $4.2 \times 10^{-7}$ & $\sim 0$ \\
\hline \multirow[t]{2}{*}{ Category 9} & 0 & 0 & $0.7 \mathrm{~K}$ \\
\hline & $8.3 \times 10^{-5}$ & $7.6 \times 10^{-4}$ & $29.2 \mathrm{~K}$ \\
\hline Without V: & $3.7 \times 10^{-5}$ & $4.1 \times 10^{-4}$ & 18. $2 \mathrm{~K}^{\circ}$ \\
\hline
\end{tabular}

BWR

\begin{tabular}{|c|c|c|c|}
\hline$\alpha$ & $2.2 \times 10^{-6}$ & $5.1 \times 10^{-5}$ & $0.9 \mathrm{~K}$ \\
\hline$B$ & $4.1 \times 10^{-\varepsilon}$ & $2.9 \times 10^{-6}$ & $0.1 \mathrm{~K}$ \\
\hline$\gamma$ & $3.6 \times 10^{-6}$ & $1.3 \times 10^{-3}$ & $23.4 \mathrm{~K}$ \\
\hline$\gamma^{\prime}$ & $5.6 \times 10^{-6}$ & $4.0 \times 10^{-4}$ & $10.9 \mathrm{~K}$ \\
\hline 0 & $\sim 0$ & $2.0 \times 10^{-8}$ & $\sim 0$ \\
\hline$\epsilon$ & $\sim 0$ & $\sim 0$ & $\sim 0$ \\
\hline \multirow[t]{2}{*}{ Category 5} & 0 & $8.1 \times 10^{-5}$ & 1. $1 \mathrm{~K}$ \\
\hline & $1.1 \times 10^{-5}$ & $1.8 \times 10^{-3}$ & $36.4 \mathrm{~K}$ \\
\hline
\end{tabular}


PWR

BWR

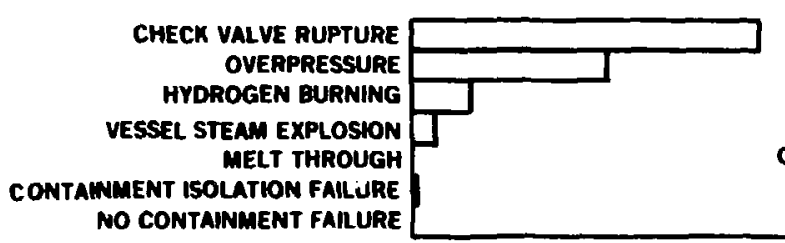

EARLY FATALITIES

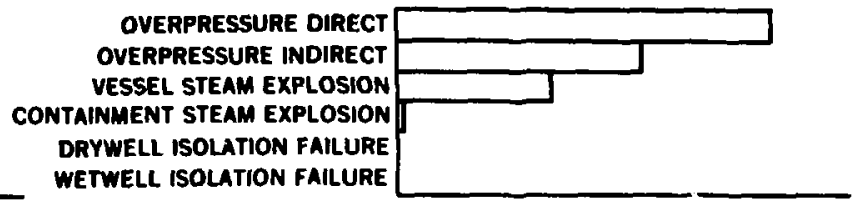

EARLY FATALITIES

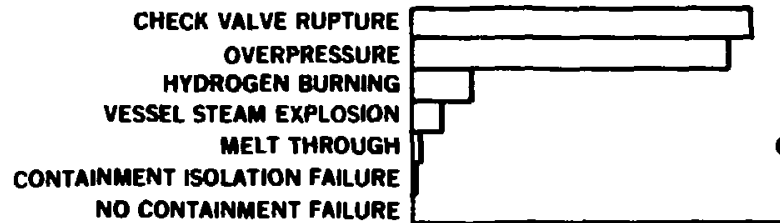

LATENT CANCER FATALITIES
OVERPRESSURE DIRECT OVERPRESSURE INDIRECT VESSEL STEAM EXPLOSION CONTAINMENT STEAM EXPLOSION DRYWELL ISOLATION FAILURE WETWELL ISOLATION FAILURE

LATENT CANCER FATALITIES

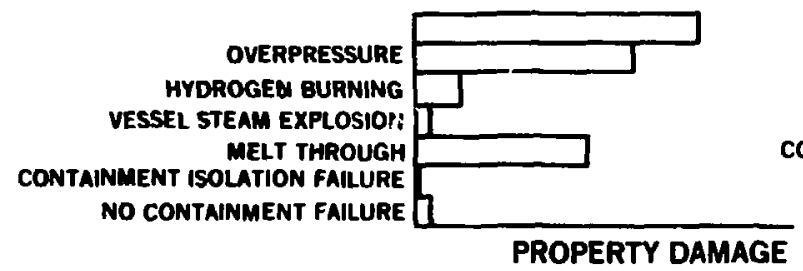

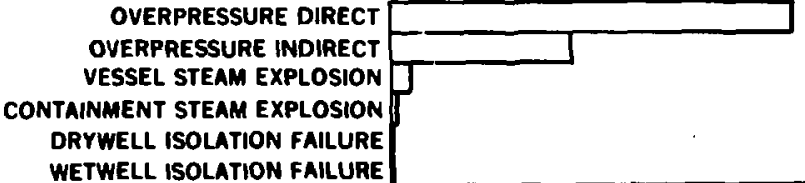

PROPERTY DAMAGE

Figure 1. Relative Importance of Containment Failure Modes 


\section{Alternate Containment Concepts}

To develop the alternate containment designs for use in the value-impact assessment, fundamental concepts that could be employed to yielal a reduction in risk were identified. On]y PWRs were considered for the rest of the study. Many concepts and alternatives were initially considered; however, the study emphasized those concepts that would inhibit overpressure failures.

The relative contribution to pressure of the gases present in containment at the time of overpressure failure for a typical accident in a PWR is shown in Jigure 2. This rigure is based on the results of the Reactor Safety Study. The potential overpressure failures which most affect risk result principally from the steam and noncondensable gases generated during the core meltdown accident. The additional heat produced by hydrogen burning, for example, has a minimal effect on rlsk. Thus, containment design alternatives which only prevented hydrogen burning were not expected to result in significant risk reduction. SLx fundamental concepts were selected for evaluation. These are shown in Table VIII.

\section{RELATIVE CONTRIBUTIONS TO PWR CONTAINMENT FAILURE PRESSURE}

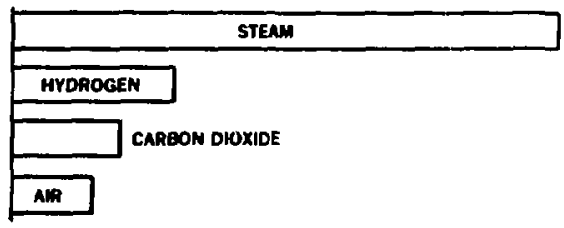

RELATINE CONTRIOUTIONS TO BWR CONTAINMENT FALLURE PRESSURE

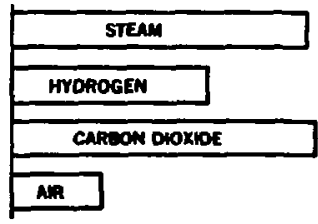

Figure 2. Relativc Contributions to Containment Failure Pressure: 
TABLE VIII

Alternate Containment Concepts

\author{
Increase Containment Design Pressure \\ Increase Containment Volume \\ Vent Containment Gases During Core Meltdown Accidents \\ Condense Containment Steam Generated During Core \\ Meltdown Accidents \\ Lower Containment Operating Pressure \\ Inhitit Accumulation of Noncondensable Gases During Core \\ Meltdown Accidents
}

\title{
Containment Design Alte matives
}

For each of these concepts, one or more design altematives were formulated. For each design alternative, design goals were defined in a manner that would give the design alternative the most favorable value-impact position. The definitions of these conceptual designs were sufficiently detailed to allow a meaningful value-impact assessment to be performed. The design alternatives selected for each concept are described below.

Increase Contalmment Design Pressure -- Two fundamental methods of increasing the containment design pressure were selected. These involved increasing the strength of the traditional design of surface containment buildings, or burying the containment structure thereby gaining the additional pressure capability resulting from the lithostatic pressure of the soil and moisture overburden. Both shallow and deep underground burial were consiaered.

Increase Containment Volume -- Only cne basic design alternative was developed to achieve increased gas containment capability through increasing the contairment free volume. This alternative was based on simply increasing the size of a traditionally designed and constructed containment butlding.

Vent Containment Gases - - Three fundamental methods were selected for venting containment gases before overpressure failure du.'ing a core meltdown accident, thus preventing the uncontrolled atmospheric release of radioactive materials. The first method was to sense pressure butldup during a core meltdown accident and to vent to the atmosphere through a filter thereby reducing the resulting consequences, This alternative was called Filtered Atmospheric Venting. The second method evaluated was simflar to the CANDU containment concept. This method was also based on sensing pressure bulldup in containment during a core meltdown accident and venting. However, In this case the containment gases would be vented to a standby containment-1ike structure, one per reactor site, equipped with sprays to condense steam. This alternative was called Compartment venting. The third method resulted from the observation that much smaller consequences were predicted by the Reactor Safety Study when the molten core melted through the base mat of the 
reactor building before overpressure failure of the containment occurred. Thus, a design alternative was considered in which the base mat was thinner than traditional designs. It was hoped that it could be shown that this would result in earlier melt-through of the base mat, thus leading to early pressure release into the ground thereby preventing atmospheric release via containment overpressure failure. This alternative was called Thinned Base Mat.

Condense Steam -- Two design approaches were considered for achieving greater steam condensation during a core-meltdown accident. They were use of an ice condenser and use of a pressure suppression pool. Although ice condensers are used to significantly reduce containment pressure for design basis accidents, this study was interested in the capability of an ice condenser to prevent overpressure failures in a core-meltdown accident. The duration of the study did not allow this to be investigated with sufficient thoroughness to perform a meaningful value-impact assessment. Use of a pressure suppression pool to condense steam was incorporated in the Filtered Atmospheric Venting alternative for both steam condensation and filtration purposes. Thus, no design alternative was included in the final value-impact assessment which exclusively implemented the condensing steam concept.

Lower Contalnment Operating Pressure -- A design alternative was developed to inhípit the combustion of hydrogen generated furing a core melt accident. A containment with a low operating pressure, thus a low oxygen inventory, was included in the value-impact assessment. This design alternative was called Evacuated Containment.

Inhibit Gas Accumulation -- No method of preventing the generation of noncondensable gases or of absorbing generated gases was found during the course of the study which was judged worthy of being included in the final value-impact assessment.

Other -- Throughout the study the subject of double containment repeatedly arose; therefore, It was included as a design alternative. The design goals used were such that the total gas containment capability of both containments was similar to current containments.

This phase of the study resulted in the selection of nine design alternatives for use in the value-impact assessment. These are summarized in Table $\mathbb{K}$, and the assumed effect on containment fallure modes for each alternative are shown in Table $\mathrm{x}$. 
TABLE IX

\author{
Containment Design Alternatives Used in \\ Value-Impact Assessment \\ Stronger Containment \\ Shallow Underground Siting \\ Deep Underground Siting \\ Increased Contatnment Volume \\ Filtered Atmospheric Venting \\ Compartment Venting \\ Thinned Base Mat \\ Evacuated Containment \\ Double Containment
}

TABLE X

Asgumed Effect on Containment Fallure Modes for Each Design Alternative

\section{Alternative}

Fintered Atmospheric Venting

Compartment Venting

Deep Underground Siting

Stronger Containment

Increased Containment Volume

Shallow Underground Siting

Evacuated Containment

Double Containment

Thinned Base Mat
Containment Failure Mode

\begin{tabular}{|c|c|c|c|c|}
\hline VSE & $\underline{\mathrm{CL}}$ & HB & $\underline{\text { OP }}$ & MIT \\
\hline$\tau$ & $\mathbf{U}$ & $\mathbf{E}^{\prime}$ & $\mathbf{E}^{\prime}$ & I \\
\hline $\mathbf{U}$ & $\mathbf{U}$ & $E^{\prime}$ & $\mathbf{E}^{\prime}$ & $I$ \\
\hline $\mathbf{E}$ & I & $\mathbf{E}$ & $\mathbf{E}$ & I \\
\hline $\mathbf{U}$ & $\mathbf{U}$ & $\mathbf{R}$ & $\mathbf{R}$ & $I$ \\
\hline $\mathrm{U}$ & $\mathrm{U}$ & $\mathbf{R}$ & $\mathbf{R}$ & I \\
\hline $\mathrm{U}$ & $\mathbf{R}$ & $\mathbf{R}$ & $\mathrm{R}$ & 1 \\
\hline $\mathbf{U}$ & $\mathbf{U}$ & $\mathbf{E}^{\prime}$ & $\mathbf{R}$ & 1 \\
\hline $\mathbf{R}$ & $\mathbf{R}$ & $\mathbf{U}$ & $\mathrm{U}$ & $\mathbf{U}$ \\
\hline $\mathbf{U}$ & $\mathrm{U}$ & $\mathbf{R}$ & $\mathbf{R}$ & I \\
\hline
\end{tabular}

\footnotetext{
Legend: VSE $=$ vessel steam explosion

CL $=$ contafnment leakage

$\mathrm{HB}=$ hydrogen $\mathrm{t} \cdot$ 'ning

OP = overpreserire

MT = melt-through of base mat

$\mathrm{U}=$ unaffected by design alternative (same as current surface plants)

$R=$ reduced by design alternative (less probable than current surface plants)

$\mathbf{E}=$ eliminated by design alternative

$E^{\prime}$ a eliminated by design alternative unless active components fall

$I=$ increased by design alternative (more probable than current surface plants)
} 
For each design alternative selected for the value-impact assessment, design goals were established. The design goals were selected to meet two criteria: (1) that they be feasible with current technology, and (2) that they result in the most favorable value-impact position for the design alternative. Each design alternative and its design goals are described below.

\section{Stronger Containment}

To increage the pressure capabilities of containment, the study examined the alternative of constructing a stronger containment by increasing the wall thickness. This altemative is illustrated in Figure 3 .

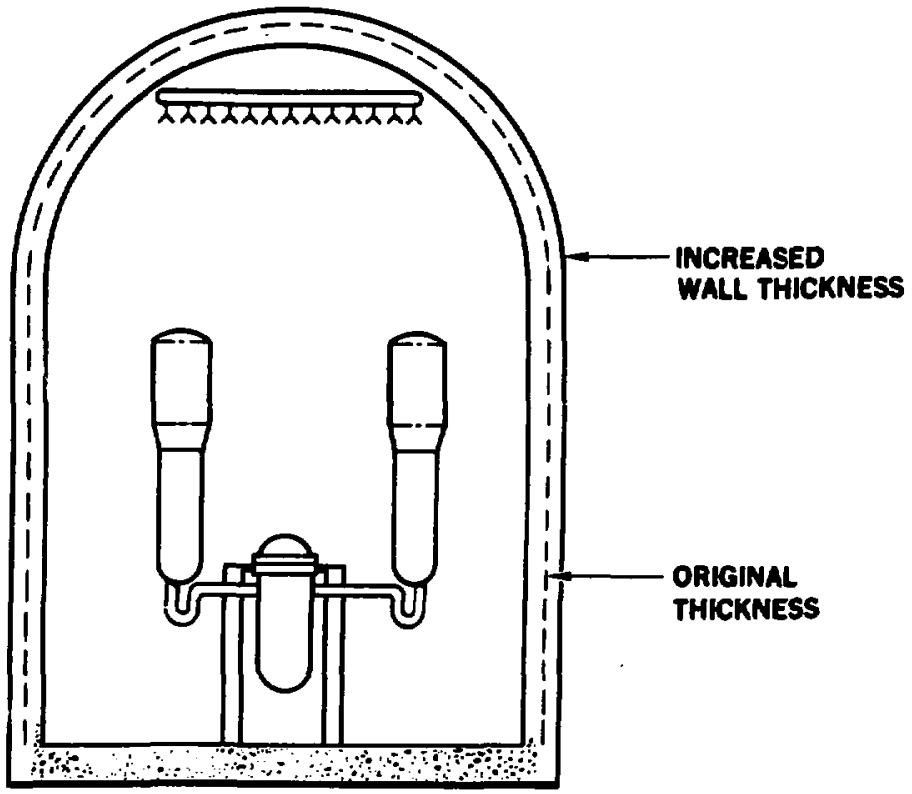

Figure 3. Stronger Containment

Accident sequences regulting in overpressure fallure can be divided into two categories.

Firat are those loss of coolant accident (LOCA) sequences in which the containment spray systems fall but the emergency core cooling system (ECCS) operated, For these sequences, the containment 
pressure builds following a LOCA and may reach several hundred psi. In this case, containment overpressure is expected to precede core melt. In the other case, both the containment heat removal systems and the ECCS fail duritg injection or recirculation. For these sequences, core melt tends to precede containment overpressure failure. The pressure may rise as high as about $120 \mathrm{psia}$, but generally melt-through or condensation on cold surfaces will limit the pressure so that overpressure failure is not certain. It is believed to be very difficult to design a containment to withstand the several hundred psi pressures of the first category of accidents. Therefore, the design goal for the stronges containment was to contain the second category of accidents; the design pressure was set at 120 psia estimated to result in an approximate doubling of the thickness of the walls, At this design pressure, the containment should be able to withstand the pressure generated in all dominant overpressure sequences in the Reactor Safety Study except those I.OCA sequences in which the containment spray systems fail but the ECCS operates.

\section{Shallow Underground Siting}

The shallow underground siting alternative, illustrated in Figure 4, was as sumed to involve placing a standard containment under about 30 feet of overburden, thus increasing the pressure capabilities of the structure due to the Iithostatic pressure of the overburden. The turbine generator building was assumed to be above grade. Shallow underground siting alternatives are currently under consideration in Germany. Their designs, however, entail a much larger containment volume. This study assumed the same containment volume as a surface plant.

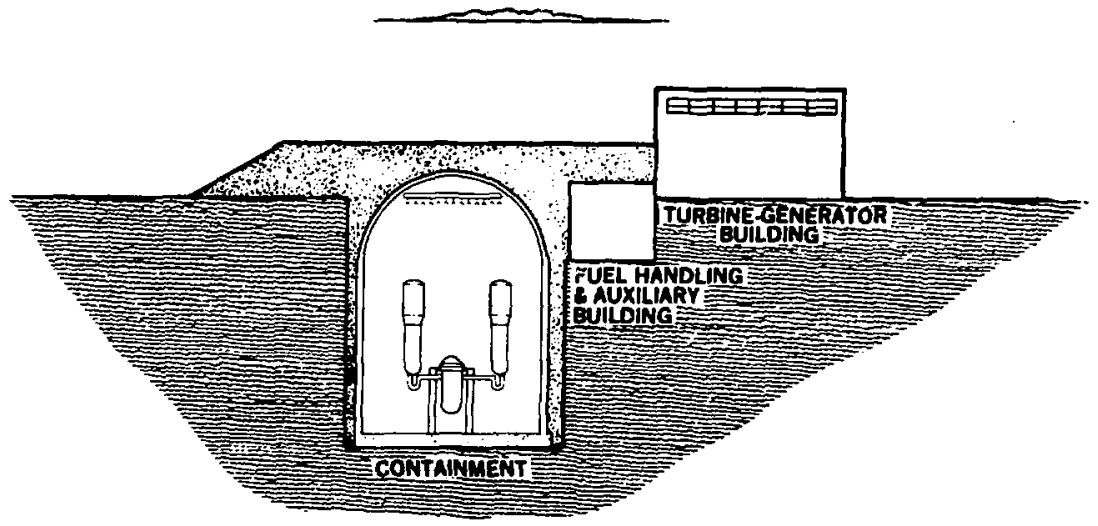

Figure 4. Shallow Underground Siting

\section{Deep Underground Siting}

The deep underground siting alternative considered in this study is shown in Figure 5. It was assumed that the top of the containment structure would be at least 100 feet underground with the turbine generator bullding located $s$ at the surface. The pregsure capablities of the containment 
would be enhanced by the lithostatic pressure of the overburden although there would still be several access passages to the surface. This alternative would involve construction of a containment similar in size and design requirements to a surface structure with modifications to enable it to withstand the external load exerted by the overburden. All passageways exiting the containment would be sealed during operation, and those passageways to the surface would be sealed at the surface in the event of an zccident.

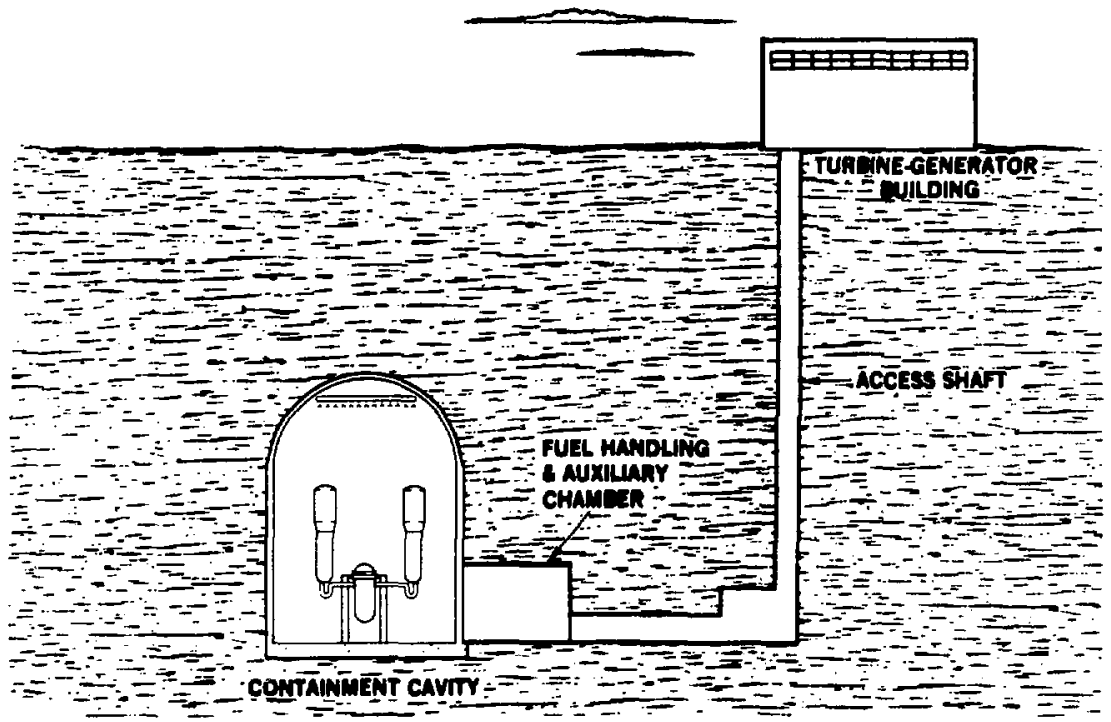

Figure 5. Deep Underground Sitting

\section{Increased Containment Volume}

Another means of increasing the gas containment capabilities of a PWR containment would involve increasing the contalnment volume as jlustrated in Figure 6, For this alternative, it was assumed that the design pressure would remain at 60 psia and that the volume would be approximately doubled. To accommodate such an increase in volume, It is assumed that the wall thickness would be increased by about one foot. This alternative would be expected to achleve the same benefits discussed in the stronger containment alternative. That is, overpressure fallures would not be signlficantly inhlbited for those LOCA accidents in which the containment spray systems fall but the ECCS operates; for other core melt accidents overpressure fallure of the contalnment would not be expected. 

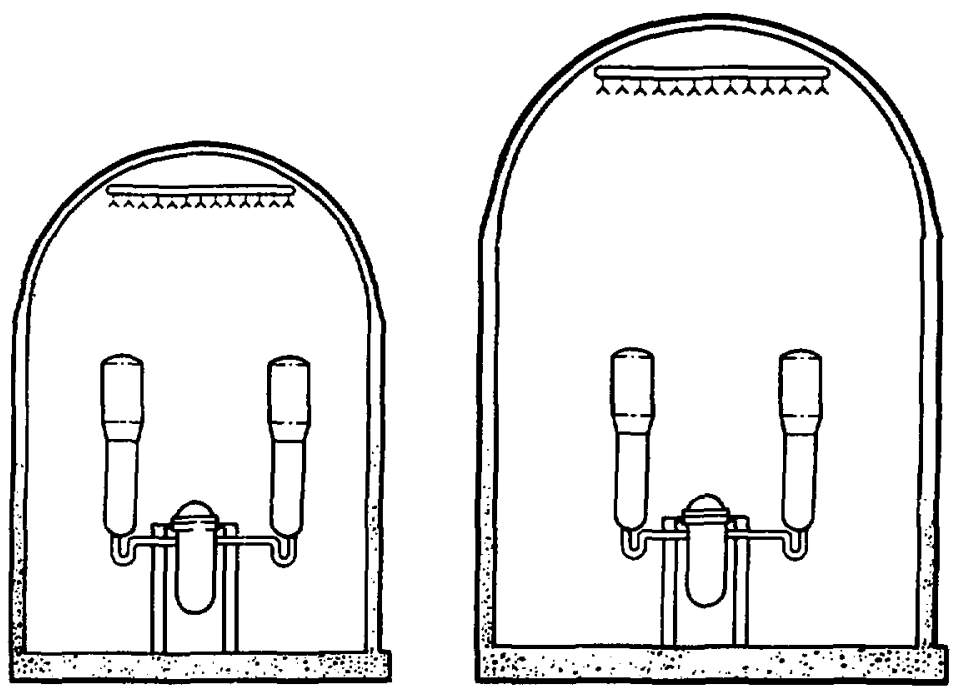

Figure 6, Increased Containment Volume

\section{Filtered Atmospheric Venting}

The filtered atmospheric venting alternative is illustrated in Figure 7. This alternative assumed use of a pressure suppression pool, envisioned as being placed external to the containment, to reduce the pressure in containmeat following a core-meltdown accident. Containment gases were assumed to be vented to the atmosphere following filtration by the water in the tank. It is assumed that venting would be achieved automatically upon sensing a pressure which is near but slightly above the containment design pressure ( $60 \mathrm{psia})$. The goal would be to assure, for the range of significant meltdown accidents, that the containment design pressure would not be greatly exceeded. It is assumed that relief valves would open under the increased pressure; thus, the containment would remain isolated unless a significant buildup in pressure occurred. Redundant systems and backup manual control would probably be advisable for these valves, The tank would contain enough water to allow condensation of all the steam generated. To ensure that large bubbles do not form, thus reducing the effectiveness of the filter, the steam should probably enter the tank through many small openings. It was assumed that the water would remove almost all of the radioactive contaminants except for the noble gases which would be vented out a stack.

\section{Compartment Venting}

This alternative, shown in Figure 8 , is simllar, in princlple, to the vacuum bullding used in the Canadian CANDU design. For thls alternative, a separate, high pressure (60 psia) containment structure was assumed to be constructed, one per reactor site, into whlch the containment atmosphere would be vented in the event of a core-meltdown accident. As in the flitered atmospheric 
venting alternative, venting was assumed to be achicved automatically by opening valves in the connecting piping when containment pressure rises to near design prescurc. The auxiliary containment was assumed to be equipped with an elevated water tank which would spray by gravity feed upon sensing a rise in pressure. This spray would condense the incoining steam and allow further pressure reduction in both struetures. Spray openings would be sized to spray until the molten core would be expected to have melted through the base mat, thus relicving containment pressure to the ground. The likelihood of overpressure failure would be exjected to be greatly reduced.

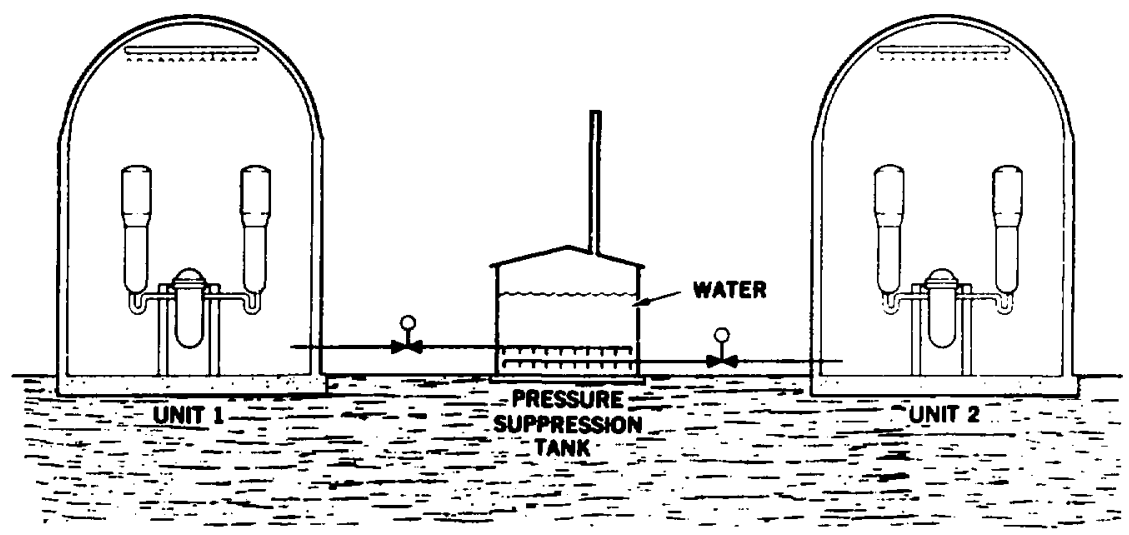

Figure 7. Filtered Atmospheric Venting

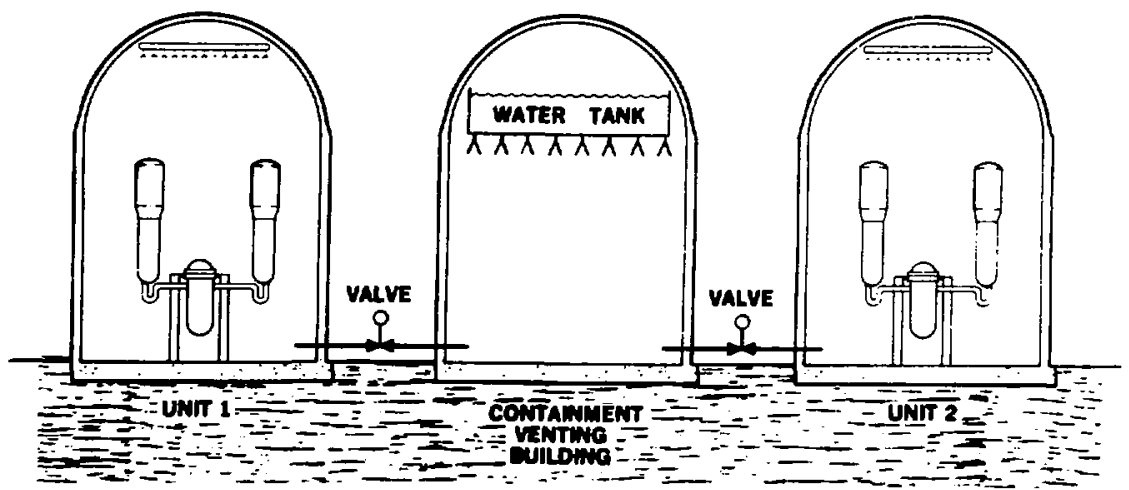

Figure 8. Compartment Venting 


\section{Thinned Base Mat}

The thinned base mat al ternative is illustrated in Figure 9. Current plants have concrete base mats approximately ten feet thick. While no optimal thickness was determined, the concrete under the reactor pressure vessel does r,ot appear to support any loads, so a significant reduction in thickness of the hase mat appears feasible. In addition to hastening the melt-through process and thus reducing the overpressure failure probability of selected accident sequences, less noncondensable gases, in particular carbon dioxide and hydrogen, would be expected to be produced irom the iuteraction of the core on the concrete.

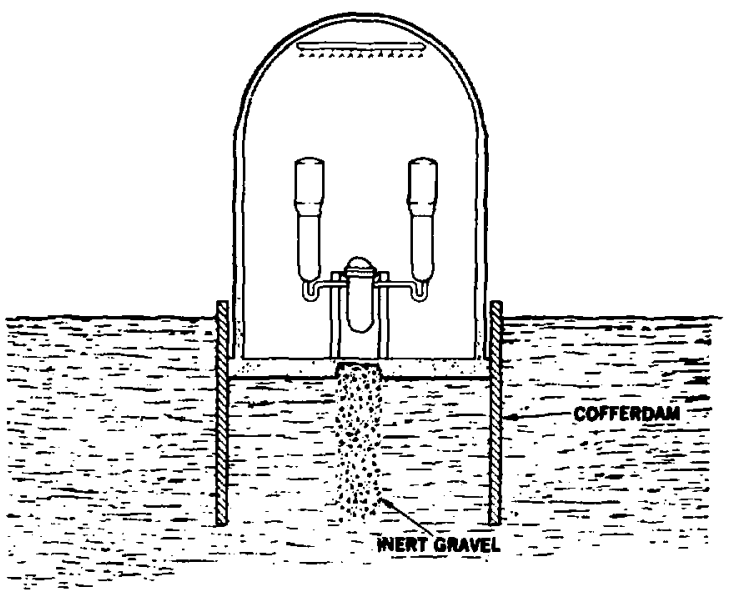

Figure 9. ThInned Base Mat

\section{Evacuated Containment}

Many plants currently operate at pressures slightly subatrospheric to reduce the normal leakage of gases from the containment. The Surry reactor examined in the Reactor Safety Study operates at about 10 psia. To reduce the likelthood of hydrogen burning, the evacuated containment alternative, shown in Figure 10, was assumed to have about a 5 psia containment, regulting in about 1 psia partlal pressure $\mathrm{O}_{2}$. Thus, a algnificant reduction of the chance of hydrogen ignition would be expected. Reduction of the internal pressure to this level should be possible using a steam powered vacuum pump.

\section{Double Containment}

The double containment alternative, Ilustrated in Figure 11, is used frequently in exlsting containments. The outer wall, however, generally can withatand only minor pressure dirierentials, its primary tunction being to protect the inner wall from external mlesiles. This atudy exarnined 
strengthening the outer wall such that it would have a gas contalnment capability equivalent to the inner wall. Thus, failuse of the inner wall would not necessarily lead to an escape of radtoactivity. In the case of overpressure fallure, however, it is likely the outer wall would soon be subjected to pressures similar to those exerted on the inner wall and, as a result, would also fall. To ensure that the concept of double containment was judged on its own merits, the volume within the outer wall was mode equivalent to current plants; that is, no benefits resulting from increasing the volume of the containment were allowed. Deaplte this restriction, it appears that this alternative would offer some benefits in event of internal missiles and could reduce the likelihood of containment isolation failure hecause of redundant seals on the penetrations.

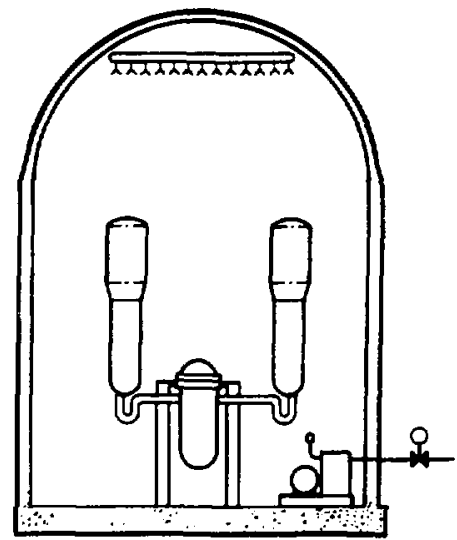

Figure 10. Evacuated Contalnment

Figure 11, Double Containment

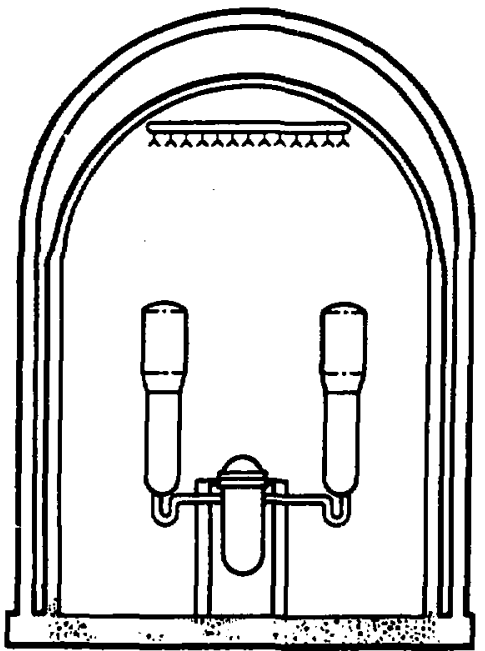


In considering the value of alternate containnent designs, each alternative was considered separately. Combinations of alternatives could have been considered, but the objective was to evaluate each alternative on its own merits rather than to identify an optlmal design combination.

Potential risk reduction resulting from implementation of the alternate containment designs was used as the principal measure oi value. To determine the potential risk reduction for each alternative, the dominant PWR accident sequences from the Reactor Safety Study were analyzed for each design alternative assuming the design goals had been achieved. The containment failure modes and their probabilities for each sequence were determined, and the probability of each accident sequence was calculated for each alternative. Using these probabilities and the expected values of consequences given a release, the expected values of the risk were obtained as in Chapter II. The results for each alternative are discussed below.

The study concluded that the design alternatives resulting in the most significant potential risk reductions were Filtered Atmospheric Venting, Containment Venting, and Deep Underground Siting. Stronger Containment and Increased Containment Volume resulted In modest potential risk reductions. The remaining design alternatives did not meaningfully reduce the risk.

\section{Flltered Atmospheric Venting}

The evaluation of filtered atmospheric venting assumed that the pressures generated following an accident could successfully be relieved through the filtration system. As a result, overpressure failures and hydrogen burning fallures would essentially be eliminated, and those sequences which would have caused containment failure by these modes would now cause containment melt-through failures. For purposes of determining potential risk reduction, it was assumed that no overpressure failures or hydrogen burning failures would occur. Since the melt-through sequences result in a much lower release category (category 6 rather than categories 2 or 3 ), the risks assoclated with the filtered atmospheric venting alternative would be considerably less. Results of the calculation of the expected values of the risks for this alternative, by containment failure mode, are given in Table XI. As can be seen, the expected values of both early fatalities per year and latent cancer fatalities per yeas per year could potentially be significantly reduced. The potential property damage risk would be only modestly reduced due to the high cost of evacuation which is assumed to take place for the melt-through accidents. Allowing a failure rate of 0.01 for the venting system did not noticeably affect the risk results. 
TABLE XI

Expected Values of Risk for Filtered Atmospheric Venting

\begin{tabular}{|c|c|c|c|}
\hline $\begin{array}{l}\text { Containment } \\
\text { Failure Mode }\end{array}$ & $\begin{array}{c}\text { Early } \\
\text { Fatalities/Yr }\end{array}$ & $\begin{array}{c}\text { Latent Cancer } \\
\text { Fatalities } / \mathrm{Yr} / \mathrm{Yr}\end{array}$ & $\begin{array}{c}\text { Property } \\
\text { Damage/Yr }\end{array}$ \\
\hline$\alpha$ & $2.9 \times 10^{-6}$ & $2.8 \times 10^{-5}$ & $0.6 K$ \\
\hline$\beta$ & $\sim 0$ & $4.2 \times 10^{-7}$ & $\sim 0$ \\
\hline$\gamma$ & 0 & 0 & 0 \\
\hline$\delta$ & 0 & 0 & 0 \\
\hline$\epsilon$ & 0 & $1.5 \times 10^{-5}$ & $7.7 \mathrm{k}$ \\
\hline Category 9 & 0 & 0 & $0.7 \mathrm{~K}$ \\
\hline & $2.9 \times 10^{-6}$ & $\overline{4.3 \times 10^{-5}}$ & $0.0 \mathrm{~K}$ \\
\hline $\begin{array}{l}\text { Current } \\
\text { Plants }\end{array}$ & $3.7 \times 10^{-5}$ & $4.1 \times 10^{-4}$ & $18.2 \mathrm{~K}$ \\
\hline
\end{tabular}

\section{Compartment Venting}

The compartment venting alternative appears to offer a similar potential for reducing the public risk. Rather than some gases escaping through the stack as in the previous alternative, however, all radioactive products are assumed to be retained in the auxiliary and primary containments. Some difference in consequences between these alternatives would result, but this was not pursued in this study. Again, it was assumed overpressure and hydrogen burning failures would essentially be eliminated with a subsequent increase in melt-through failures. Results of the risk calculations, shown in Table XII, are the same as for the previous alternative, A potentially significant reduction in fatality risks appears to exist along with a modest reduction in property damage risk. It may be added that some active components, e.g., valves, must operate for each of these alternatives. Allowing a failure rate of 0.01 for the system did not noticeably affect the risk results.

TABLE XII

Expected Values of Risk for Compartment Venting

\section{Containment \\ Fallure Mode}

$\alpha$

$\boldsymbol{\beta}$

$\gamma$

$\delta$

e

Category 9

Current

Plantg:

\begin{tabular}{c}
$\frac{\text { Early }}{\text { Fatalities } / \mathrm{Yr}}$ \\
\hline $2.9 \times 10^{-6}$ \\
$\sim 0$ \\
0 \\
0 \\
0 \\
0 \\
\hline
\end{tabular}

$2.9 \times 10^{-6}$

$$
3.7 \times 10^{-5}
$$

Latent Cancer Fatalities/Yr/Yr

$$
\text { 2. } 8 \times 10^{-5}
$$$$
4.2 \times 10^{-7}
$$$$
0
$$

0

$1.5 \times 10^{-5}$

$\frac{0}{4.3 \times 10^{-5}}$

4. $1 \times 10^{-4}$
Property Damage/Yr

$0.6 \mathrm{~K}$

$\sim 0$

$$
0
$$

0

7. $7 \mathrm{~K}$

0. $7 \mathrm{~K}$

9. OK

*excluding check valve rupture aequences 


\section{Deep Underground Siting}

The lithostatic pressure of the overburden for the deep underground siting, al ternative should add approximately 100 psi pressure capability to the containment. As a result, those sequences in which the maximum pressure only slightly exceeds the design pressure of surface containments would probably be contained and would result in melt-through failures. Complete failure of containment as a result of missiles generated by steam explosions would also be unlikely. For those high pressure sequences discussed previously in which the containment spray systems fail, it was assumed that the seals in the access passages would fail under the high pressures (several hundred psi), resulting in a puff release at the surface with consequences similar to normal overpressure failures. These sequences were called containment isolation failures $(\beta)$ and were assigned to release category 2 or 3 depending on the sequence. While the seals may fail under high pressures, the existence of two sets of seals would significantly reduce the probability of containment isolation failure for reasons other than high pressure. The possibility of the containmant structure failing with subsequent filtration of the release by the overburden was not considered in detail. The results of the risk calculations are shown in Table XIII. The early fatality risk would potentially be reduced significantly. The latent cancer fatality risk would be predicted to be modestly reduced; much of the latent cancer fatality risk arises from the overpressure fallure mode which would still remain in the form of high pressure containment isolation failures. The property damage risk would be only slightly reduced as a result of the high evacuation cost. The consequence calculation for the meltthrough case was not redone even though the release would be several hundred feet underground. In addition, the influence of impermeable versus permeable rock external to containment was not considered.

TABLE XIII

Expected Values of Risk for Deep Underground Siting

\begin{tabular}{|c|c|c|c|}
\hline $\begin{array}{c}\text { Containment } \\
\text { Failure Mode }\end{array}$ & $\begin{array}{c}\text { Early } \\
\text { Fatalities/Yr }\end{array}$ & $\begin{array}{c}\text { Latent Cancer } \\
\text { Futalities/Yr/Yr }\end{array}$ & $\begin{array}{l}\text { Property } \\
\text { Damage/Yr }\end{array}$ \\
\hline$\alpha$ & 0 & 0 & 0 \\
\hline$A$ & $3.6 \times 10^{-6}$ & $1.5 \times 10^{-4}$ & $3.0 \mathrm{~K}$ \\
\hline$\gamma$ & 0 & 0 & $\mathbf{0}$ \\
\hline$\delta$ & 0 & 0 & 0 \\
\hline$\epsilon$ & 0 & $1.1 \times 10^{-5}$ & 7. IK \\
\hline \multirow[t]{2}{*}{ Category 9} & 0 & 0 & $0.7 \mathrm{~K}$ \\
\hline & $3.6 \times 10^{-6}$ & $1.6 \times 10^{-4}$ & $10, \mathrm{BK}$ \\
\hline $\begin{array}{l}\text { Current } \\
\text { Plantst }\end{array}$ & $3.7 \times 10^{-5}$ & 4. $1 \times 10^{-4}$ & 1B. $2 K$ \\
\hline
\end{tabular}




\section{Stronger Containment}

The stronger containment was assumed to be designed for a pressure of 120 psia. As such, only those LOCA sequences in which the containment spray systems fail but the ECCS operates would be expected to fail the containment by overpressure. All other overpressure and hydrogen burning sequences should be contained and ultimately result in melt-through failures of less consequence. In this alternative and in many of the others, the failure of the containment due to overpressure would be delayed resulting in increased evacuation time and a potential decrease in early fatalities. This delay time, however, has not been considered in the calculations. Results of the calculation of the expected values of the risk for this alternative are given in Table XIV. The potential early fatality risk reduction would be significant whereas the potential reduction in latent cancer fatality and property damage risks would be more modest.

TABLE XN

Expected Values of Risk for Stronger Containment

\begin{tabular}{|c|c|c|c|}
\hline $\begin{array}{r}\text { Containment } \\
\text { Failure Mode } \\
\end{array}$ & $\begin{array}{c}\text { Early } \\
\text { Fatalities/Yr }\end{array}$ & $\begin{array}{c}\text { Latent Cancer } \\
\text { Fatalities } / \mathrm{Yr} / \mathrm{Yr}\end{array}$ & $\begin{array}{c}\text { Property } \\
\text { Damage/Yr }\end{array}$ \\
\hline$\alpha$ & $2.9 \times 10^{-6}$ & $2.8 \times 10^{-5}$ & $0.6 \mathrm{~K}$ \\
\hline$\beta$ & $\sim 0$ & $4.2 \times 10^{-7}$ & $\sim 0$ \\
\hline$\gamma$ & 0 & 0 & 0 \\
\hline$\delta$ & $3.6 \times 10^{-6}$ & $1.5 \times 10^{-4}$ & $3.0 \mathrm{~K}$ \\
\hline$\epsilon$ & 0 & $1.1 \times 10^{-5}$ & 7. $1 k$ \\
\hline Category 9 & 0 & 0 & $0.7 \mathrm{~K}$ \\
\hline & $6.5 \times 10^{-6}$ & $1.3 \times 10^{-4}$ & $11.4 \mathrm{~K}$ \\
\hline $\begin{array}{l}\text { Current } \\
\text { Plants }\end{array}$ & $3.7 \times 10^{-5}$ & $4.1 \times 10^{-4}$ & $18,2 \mathrm{k}$ \\
\hline
\end{tabular}

\section{Increased Containment}

The increased containment volume alternative was assumed to have design goals similar to the stronger containment discussed above. $\Lambda s$ such, the potential risks calculated for this alternative, shown in Table XV, would be the same as for the stronger containment al te rnative. 
TABLE XV

Expected Values of Risk for Increased Containment Volume

\begin{tabular}{|c|c|c|c|}
\hline $\begin{array}{r}\text { Containment } \\
\text { Failure Mode }\end{array}$ & $\begin{array}{c}\text { Early } \\
\text { Fatalities/Yr }\end{array}$ & $\begin{array}{c}\text { Latent Cancer } \\
\text { Fatalities/Yr/Yr }\end{array}$ & $\begin{array}{c}\text { Property } \\
\text { Damage/Yr }\end{array}$ \\
\hline$\alpha$ & $2.9 \times 10^{-6}$ & $2.8 \times 10^{-5}$ & $0.6 \mathrm{~K}$ \\
\hline$\beta$ & $\sim 0$ & $4.2 \times 10^{-7}$ & $\sim 0$ \\
\hline$\gamma$ & 0 & D & 0 \\
\hline 6 & 3. $6 \times 10^{-6}$ & $1.5 \times 10^{-4}$ & $3.0 \mathrm{~K}$ \\
\hline $\boldsymbol{E}$ & 0 & $1.1 \times 10^{-5}$ & $7.1 \mathrm{~K}$ \\
\hline \multirow[t]{2}{*}{ Category 9} & 0 & 0 & $0.7 \mathrm{~K}$ \\
\hline & $6.5 \times 10^{-6}$ & $1.9 \times 10^{-4}$ & $11.4 \mathrm{~K}$ \\
\hline $\begin{array}{l}\text { Current } \\
\text { Plants }\end{array}$ & $3.7 \times 10^{-5}$ & $4.1 \times 10^{-4}$ & $18,2 \mathrm{~K}$ \\
\hline
\end{tabular}

\section{Shallow Underground Siting}

Placing the reactor slightly below grade, as suggested in the shallow underground siting alternative, would not appezr to offer the potential for significant risk reduction, although the proposed 30 feet of overburden would somewhat reduce the risk from overpressure fillure. It is not known whether steam explusion generated missiles would penetrate both the containment and the overburden, but no credit for containing steam explosions was assumed in calculating the expected risk. As is the deep underground siting alternative, the possibility of filtration of the release by the overburden following failure of the containment structure was not considered in detail. For this alternative, however, such filtration was expected to be unlikely. Redundant seals should reduce the probability of containment isolation failure. Table XVI presents the results of the calculation of expected risks. Only modest potential reductions in risk are expected for all three types of risk considered.

\section{Evacuated Containment}

Evacuating the containment was assumed to successfully reduce the probability of hydrogen burning but was not expected to significantly affect the other containment fallure modes. Although reducing the presgure of the containment to around 5 pala would remove much of the air and, hence, the pressure in containment due to this component following accident initiation, air is predicted to contribute little to the pressure at the time of containment fallure. As shown in Figure 2, the principal components to the pressure are predicted to be steam and noncondensable gases. As a result, evacuating containment was expected to have a minimal effect on the overpressure fallure mode. Although normal loakage from the plant could be somewhat reduced, this was not considered In the probability for contalnment loolation fallure. This alternative also would not be expected to impact the vesiel steam explosion probablity. Results of the calculation of the expected values of 
risk are shown in Table XVII. Only minimal potential reductions in risk are expected to be realized by implementing this alternative.

TABLE XVI

Expected Values of lisk f̂r Shallow Underground Siting

\begin{tabular}{c}
$\begin{array}{c}\text { Containment } \\
\text { Failure Mode }\end{array}$ \\
\hline$\alpha$ \\
$\beta$ \\
$\gamma$ \\
$\delta$ \\
$\epsilon$
\end{tabular}

Category 9

Current

Plants

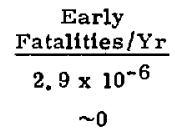

$$
\text { 4. } 4 \times 10^{-6}
$$$$
1.5 \times 10^{-5}
$$$$
0
$$

$\frac{0}{2.2 \times 10^{-5}}$

$$
3.7 \times 10^{-5}
$$

Latent Cancer Fatalities/Yr/Yr

$2.8 \times 10^{-5}$

$\sim 0$

$3.2 \times 10^{-5}$

2. $3 \times 10^{-4}$

8. $8 \times 10^{-6}$

$\frac{0}{3.0 \times 10^{-4}}$

4. $1 \times 10^{-4}$
Property Damage/Yr

$0.6 \mathrm{~K}$

$\sim 0$

1. $0 \mathrm{~K}$

5. $6 \mathrm{~K}$

6. 9 .

0. $7 \mathrm{~K}$

14. $7 \mathrm{k}$

1B. $2 K$

*excluding check valve mupture sequence

TABLE XVII

\begin{tabular}{|c|c|c|c|}
\hline $\begin{array}{l}\text { Containment } \\
\text { Failure Mode } \\
\end{array}$ & $\begin{array}{c}\text { Early } \\
\text { Fatalities/Yr } \\
\end{array}$ & $\begin{array}{c}\text { Latent Cancer } \\
\text { Fatalities/Yr/Yr }\end{array}$ & $\begin{array}{c}\text { Property } \\
\text { Damage/Yr }\end{array}$ \\
\hline$\alpha$ & $2.9 \times 10^{-6}$ & $2.8 \times 10^{-5}$ & $0.6 \mathrm{~K}$ \\
\hline$\beta$ & 0 & $4.2 \times 10^{-7}$ & $\sim 0$ \\
\hline$\gamma$ & 0 & 0 & 0 \\
\hline 6 & $2.3 \times 10^{-5}$ & $2.9 \times 10^{-4}$ & 7. $6 \mathrm{~K}$ \\
\hline E & 0 & $8.5 \times 10^{-6}$ & $6.8 \mathrm{~K}$ \\
\hline \multirow[t]{2}{*}{ Category 9} & 0 & 0 & $0.7 \mathrm{~K}$ \\
\hline & $2.6 \times 10^{-5}$ & $3.3 \times 10^{-4}$ & $15.7 K$ \\
\hline $\begin{array}{l}\text { Current } \\
\text { Plants }\end{array}$ & $3.7 \times 10^{-5}$ & $4.1 \times 10^{-4}$ & $18,2 \mathrm{k}$ \\
\hline
\end{tabular}

Expected Values of Risk for Evacuated Containment

\section{Double Contalnment}

Double containment, like the underground siting alternative, would be expected to reduce the containment isolation fallure probability as a result of redundant penetrations. As discussed previously, this alternative would appear to offer some increased protection from contalnment failure due to missiles generated by vessel steam explosions. The reduction in probability of this 
containment failure mode is highly uncertain, but this study assumed a reduction by a factor of ten. The results, however, are not very sensitive to this assurption. As can be seen in Table XVIII, the vessel steam explosion failure mode is not predicted to be a large contributor to any of the risks. The double containment al ternative would offer almost no potential reduction in risk over current surface plants.

\section{TABLE XVIII}

Expected Values of Risk for Double Containment

\begin{tabular}{|c|c|c|c|}
\hline $\begin{array}{r}\text { Containment } \\
\text { Fallure Mode }\end{array}$ & $\begin{array}{c}\text { Early } \\
\text { Fatalities / Yr }\end{array}$ & $\begin{array}{c}\text { Latent Cancer } \\
\text { Fatalities/Yr/Yr }\end{array}$ & $\begin{array}{c}\text { Property } \\
\text { Damage/Yr }\end{array}$ \\
\hline$\alpha$ & $1,1 \times 10^{-6}$ & $5.0 \times 10^{-6}$ & $0.1 \mathrm{~K}$ \\
\hline$\beta$ & $\sim 0$ & $\sim 0$ & $\sim 0$ \\
\hline$\gamma$ & $8.1 \times 10^{-6}$ & $5.9 \times 10^{-5}$ & $1.9 \mathrm{~K}$ \\
\hline$\delta$ & $2.6 \times 10^{-5}$ & $3.2 \times 10^{-4}$ & $8.4 K$ \\
\hline$\epsilon$ & 0 & $6.5 \times 10^{-6}$ & $6.6 \mathrm{~K}$ \\
\hline \multirow[t]{2}{*}{ Category $:$} & 0 & 0 & $0.7 K$ \\
\hline & $3.5 \times 10^{-5}$ & $3.0 \times 10^{-4}$ & $17.7 \mathrm{~K}$ \\
\hline $\begin{array}{l}\text { Current } \\
\text { Plants }\end{array}$ & $3.7 \times 10^{-5}$ & $4.1 \times 10^{-4}$ & $18.2 \mathrm{~K}$ \\
\hline
\end{tabular}

\section{Thinned Base Mat}

The final design alternative considered, thinning the base mat, would appear to offer no measurable reduction in risk. For those LOCA sequences in which the containment spray systems fall but the ECCS operates, the containment is predicted to fail by overpressure before core melt begins. This alternative would not affect these sequences. For those sequences in which the core melts but containment heat removal capability is not lost, the sequences already have been categorized as melt-through failures. Thinning the base mat would hasten melt-through in these cases but would not change the basic containment failure mode. While hastening melt-through in these cases may reduce the evacuation time and thereby possibly increase the potential early fatality risk, this possibllity was not considered here. For those sequences in which core melt occurs and long-term containment heat removal is lost, the overpressure failure and melt-through fallures are predicted to occur on simllar time scales, around 20 hours after accident initiation. For these cases, thinning the base mat would be expected to reduce the likelthood of overpressure fallures. Thege gequences, however, involve multiple system fallures (emergency coolant injectlon or recirculation fallure in conjunction with containment heat removal system fallure) and, as a result, are low probability sequences contributing ingigniflcantly to the risk. Table XIX shows the expected values of the risk for this case. A negligible potential reduction in risk over current plants was calculated. Site dependent properties such as the permeability of the foundation rock were not considered in this analysis, but they would have little influence on this type of an evaluation. 
TABLE XX:

Expected Values of Risk for Thinned Base Mat

\begin{tabular}{|c|c|c|c|}
\hline $\begin{array}{r}\text { Containment } \\
\text { Failure Mode } \\
\end{array}$ & $\begin{array}{l}\text { Early } \\
\text { Fatalities/Yr }\end{array}$ & $\begin{array}{c}\text { Latent Cancer } \\
\text { Fatalitiss / Yr/Yr }\end{array}$ & $\begin{array}{c}\text { Property } \\
\text { Damage/Yr }\end{array}$ \\
\hline$\alpha$ & $2.9 \times 10^{-6}$ & $2.8 \times 10^{-5}$ & $0.6 \mathrm{~K}$ \\
\hline$\beta$ & $\sim 0$ & $4.2 \times 10^{-7}$ & $\sim 0$ \\
\hline$\gamma$ & $8.1 \times 10^{-6}$ & $5.9 \times 10^{-5}$ & $1.9 \mathrm{~K}$ \\
\hline$\delta$ & $2.6 \times 10^{-5}$ & $3.2 \times 10^{-4}$ & $8.4 \mathrm{~K}$ \\
\hline$\epsilon$ & 0 & $6.5 \times 10^{-6}$ & $6.6 \mathrm{~K}$ \\
\hline \multirow[t]{2}{*}{ Category 9} & 0 & 0 & $0.7 \mathrm{~K}$ \\
\hline & $3.7 \times 10^{-5}$ & $4.1 \times 10^{-4}$ & $18.2 \mathrm{~K}$ \\
\hline $\begin{array}{l}\text { Current } \\
\text { Plants }\end{array}$ & $3.7 \times 10^{-5}$ & $4,1 \times 10^{-4}$ & $18,2 \mathrm{~K}$ \\
\hline
\end{tabular}

Table XX summarizes the results discussed above. The alternatives fall into three groups for each risk. For early fatalities, the groupings are as follows:

Significant Potential

Risk Reduction:

Modest Potential Risk

Reduction:

Marginal Potential Risk

Reduction:

\author{
Deep Underground Siting \\ Filtered Atmospheric Venting \\ Compartment venting \\ Stronger Containment \\ Increased Containment Volume \\ Thinned Base Mat \\ Double Containment \\ Evacuated Containment \\ Shallow Underground Siting
}

For latent cancer fatalities, the groupings are as follows:

Significant Potential

Risk Reduction:

Modest Potential Risk Reduction:

Marginal Potential Risk Reduction:

\author{
Filtered Atmospheric Venting \\ Compartment Venting \\ Stronger Containment \\ Increased Conta inment Volume \\ Deep Underground Siting \\ Thinned Base Mat \\ Double Containment \\ Evacuated Containment \\ Shallow Inderground Siting
}

Only deep underground siting changes groups. This is due to the relative contribution to the latent cancer fatality risk of high pressure sequences (those which cause the access passagea to fail by overpregsure) being greater than their relative contribution to the early fatality risk. 
TABLE XX

Relative Risk for Alternate Containment Designs Normalized to Current Surface Plants

Current Surface Plants

Thinned Base Mat

Double Containment

Evacuated Containment

Shallow Underground Siting

Increased Containment Volume

Stronge $r$ Containment

Deep Underground Siting

Compartment Venting

Filtered Atmospheric Venting

\begin{tabular}{cc} 
Early Fatalities \\
$\begin{array}{c}\text { Maximum } \\
\text { Expected } \\
\text { Value }\end{array}$ & $\begin{array}{c}\text { Calculated } \\
\text { Value }\end{array}$ \\
\hline
\end{tabular}

1,00

1. 00

0. 91

0.71

0.59

0. 18

0.18

0.10

0.08

0.08
1,00

1,00

1.00

0.91

0.83

0. 40

0.40

0.30

0.29

0.29

\begin{tabular}{cc} 
Latent Effects & $\begin{array}{c}\text { Maximum } \\
\text { Expected } \\
\text { Calculated } \\
\text { Value }\end{array}$ \\
\hline
\end{tabular}

1.00

1. 00

1.00

1. 00

0.91

1.00

0.83

0.83

0. 71

0.77

0.45

0. 56

0.45

0.56

0.38

0.45

0.11

0.43

0.11 * The maximum calculated value is the value of the consequence that occurs with a
probability of $10^{-9}$ per year.

\section{Complementary Cumulative Distribution Functions}

Complementary cumulative distribution functions, showing the probability distribution for various consequences, were constructed for the early fatality risk and the risk from latent cancer fatalities. These are calculated from the conditional probability distribution of the consequences for each release category and the probability of each release category. That is, for a glven consequence, $C_{j}$, for each releage category, $i$, the consequence model calculates a conditional probability, $P\left(C_{j} \mid i\right)$. Analysis of the accident sequence probabilities results in the probabllity or each release category, $\mathrm{P}(\mathrm{i})$. To obtain the absolute probability of having a consequence $\mathrm{C} \geq \mathrm{C}_{j}$ for a PWR, one performs the following summation:

$$
\sum_{i=1}^{g} P\left(C_{j} \mid i\right) P(i) .
$$

The complementary cumulative distribution function (CCDF) is the locus of points resulting from considering all $\mathrm{C}_{\mathbf{j}^{*}}$. These curves are shown in Figures 12 and 13 . The baseline case shown is the CCDF from the Reactor Safety Sturiy with the check valve sequence eliminated, The shaded regton depicts the uncertainty band assoclated with the baseline case. The CCDF's for each group prevtously discussed are shown. As can be seen, all but one of these curves lies within the predicted 
uncertainty band assoctated with current surface plants. Thus, only the alternatives in this group deep underground siting, filtered atmospheric venting, and compartment venting - appear to offer the potential for signiflcant reductions in public risk.

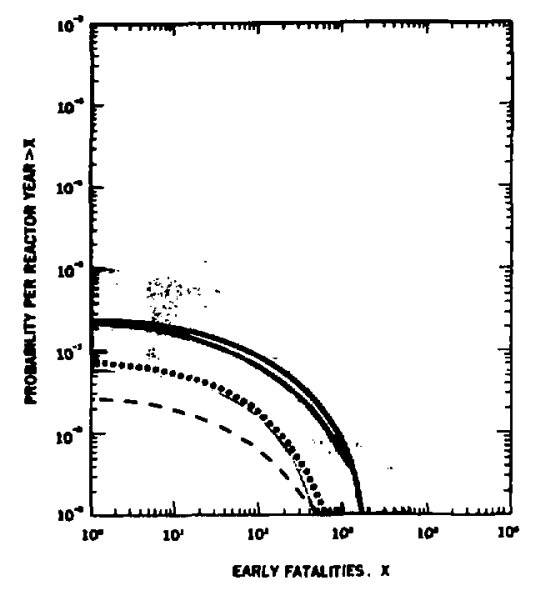

LEGEND:

- BASEL!ME CASE

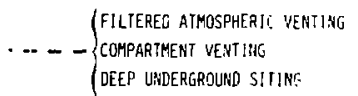

.......... \{ STRDHGER CONTAINHENT

\{ Increasen coníaliment volume

$$
\begin{aligned}
& \text { (THINMED BASE HAT } \\
& \text { - - } \text { DOUBLE CONTAIMMENT }
\end{aligned}
$$

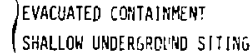

HOTE: MAGMLTUDES OF RISK PEDUCT: ON SMOW1:

FOT BE FULLY REALI ED IH AL ACTUA

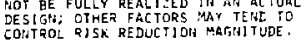

Figure 12, Probability Distribution for Early Fatalities per Reactor Year

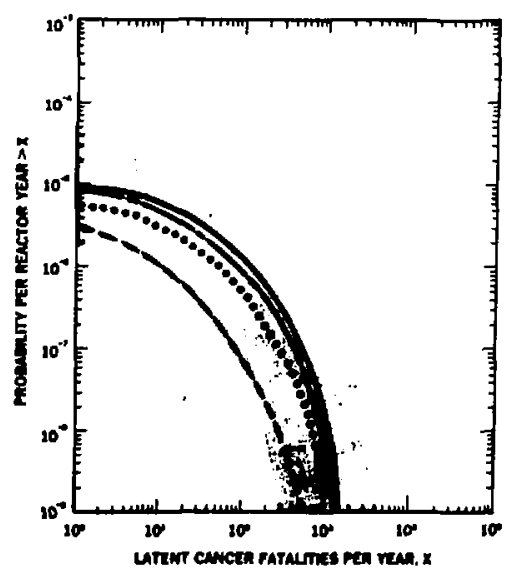

LEGEND:

BASELIME EASE

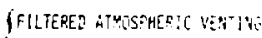

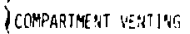

[DEEP UNDER:SODNA SITIVE

STRONGER CCNTA! NML MT

(INCREASED CONTA:HWEAT VRLUME

(THJWNED EASE MA.

DOUBLE CONTAJ NMLNT

- EVACUATED CONTA]NATET

(SHALLON UHDERGROLHD SITING

MOTE: MAGNITUDES OF RISK REDUCTION SHOWN

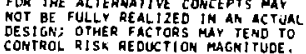

Figure 13. Probablity Distrlbution for Latent Cancer Fatalities per Reactor Year 


\section{CHAPTER VI. IMPACT ASSESSMENT}

There are eeveral ways of measuring the Impact of alternate designs. This study considered the following:

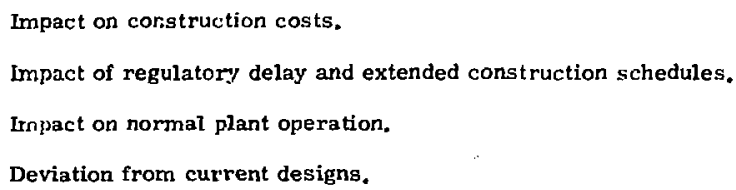

It is difficult to quantify all of these factors. Ultimately the impact assessment of alternate designs was based on the factors whtsh could be quantified along with a listing of nonquantifiable factors. It should be noted that those alternatives having the highest cost also had the longest list of nonquantifiable impact factors. Whlle the cost estimates used should be satisfactory for ranking the alternatives, they Bhould not be considered accurate actual cost estimates; the timescales of the study did not permit detailed economic analysis of the alternatives.

\section{Futered Atmospheric Venting}

The filtered atmospheric venting alternative envisioned here was assumed to involve adding a modest-sized water tank external to the existing structure. As such, the impact on the existing containment designs was assumed to be minimal, requiring only the addition of piping equipped with relief valves to channel the containment contents to the tank if the pressure reaches the containment design pressure. The tank Itself was not assumed to be elaborate. It could well be possible to use the tank for more than one unit per site. No construction delays or plant reconfiguration are anticipated, and no technological advances would appear necessary. There would, however, be increased maintenance and testing associated with the system. The final assessment of this alternative is that the impacts would be minimal compared to the other alternatives. Assuming a simple tank design, the cost associated with implementing the alternative is estimated to be on the order of a few million dollars per plant.

\section{Compartment Venting}

If venting to another compartment were to be implemented, an additional containment structure aimilar to present containments is assumed to be required ai each site. One such structure could potentlally serve more than one unit, so one per site may be sufficlent. The impact on existing designs would again be expected to be minimal, requiring only additional piping with valves running from the coniainment to the auxillary compartment. The additional structure was assumed to cost about the same as exiating contalnmente, on the order of $\$ 20$ million. It is likely that the 
auxiliary containment would have to be completely finished and tested before startup is permitted. To avert a possible extension in construction schedule, additional manpower would be required during construction, especially for a multiple unit site. It is expected, however, that such a delay could be averted, As before, no significant redesign of containment systems or plant configuration would be anticipated and no advanced technological requiremerts have been identified. Testing and maintenance similar in that for existing containments would probabjy be required for the auxiliary containment but, once completed, the impacts on nurmal plant operation are expected to be minimal. Assuming that no extension in construction schedule is requirad, the cost impacts are estimated to be on the order of $\$ 20-\$ 40$ milion.

\section{Deep Underground Siting}

In contrast to the previous alternatives, deep underground siting is expected to result in major impacts on existing designs. The containment is assumed to be covered by about 100 feet of overburden; thus, excavation at least 300 feet below grade would be required. In addition to the increased difficulties of construction, the additional piping and electrical wiring required if the turbine generator were located on the surface would increase the materials cost. The most severe cost impact expected would be the extended construction schedule: a two year extension was used for impact estimntes. Such an extension could cost well over $\$ 100$ million in increased capital costs and escalation. This cost would be expected to dominate other cost increases. Additional regulatory delays may result, at least for the first plant of this kind. Plant access and personnel mobllity may be impaired with potential major impacts on normal plant operation. Finally, the implementation of this alternative would necessitate a complete redesign of plant configuration and probably many plant systems. The impacts of this alternative would be greater that any of the other alternatives considered; in monetary terms alone this alternative was estimated to cost from $\$ 200$ - \$400 million per plant depending on the type of underground alternative chosen, A detailed discussion of the impacts of various underground siting concepts such as rock excavation versus cut-and-cover may be found in a recent underground siting study.

\section{Stronger Containment}

The stronger containment alternative was assumed to involve increasing the thickness of the walls. This would entail additional material costs, primarily concrete and steel reinforcement. The structure would require some redesign, particularly in the posttensioning system. The many penetrations and seals could require major modification and may well be more difficult to design since, at present, there are no supports within the wall for the penetrations. Support could be necessary if the thickness of the walls were significantly increased. This design alternative appears to have several advantages. No reconfiguration of the plant would be expected, no technological advances would appear necessary, and little impact on normal plant operation would result. This would also be a completely passive system, Assuming no extension of construction schedules, the cost associated with this alternative was estimated to be modest, on the order of $\$ 15-\$ 25 \mathrm{million}$.

\footnotetext{
* "Underground Siting of Nuclear Power Plants: Potential Benefits and Penaltieg," SAND76-0412, NUREG-0255.
} 
Increased Containment Volume

Increasing the containment volume is similar to the stronger containrnent alternative in many resj:ects. Both would be completely passive with rinimal expected technological and operational impacts. The increased wall area would ard to the construction cost. In ardition, the steel liner would have to be enlarged. While a larger buileling would he constructed, it was assumed this would not result in inereased construction time or regulatory selays. Work could be car ried on in other areas whlle the larger containment is under constswion. There may, however, be a complete reconfiguration of tJe containment intemals and a resultant mpact on equipment and piping. The cost for this alternative was estimated to be similar to the prevalous alternative, perhaps around $\$ 20$ - $\$ 30$ million. The inc reased cost estimate over the stronger containment ulternative was due primarlly to the inc reased liner cost.

\section{Shallow Unde rground Siting}

Many of the impacts identified for decp underground siting would apply, to a lesser extent, to the shallow underground siting alternative, Again, significant excavation to a round 200 feet was assumed to be required. $\wedge$ major redesign of plant features mity be desirable to minimize the coste of extra piping and wiring. Acress and personnel mobility may be more restrictive than for current surface plants, thus impacting the normal operation of the plant. It is expected that conventional construction techniques could be used, but that an extension of the construction schedule of one to two years may be required. Associated with this would be significant capital and escalation costs, perhaps on the order of $\$ 100$ million. While not expected to be as costly as the deep underground siting alternative, the increased costs, estimated to be $\$ 100-\$ 200 \mathrm{million}$, would be signtficant.

\section{Evacuated Containment}

Among the least costly alternatives constdered was evacuation of the containment. There would be little impact on the plant configuration and no new technological developments. Some aspects of the containment would have to bo examined to assure that external pressure requirements were met. The equipment necessary to maintain the varuum exists and should be available at minimal additional cost with no anticlpated construction delays. The greatest impact of this alternative would probably be from an operational viewpoint. This active system would entail increased maintenance and operational costs. In addition, access to the containment may be more IImited. There could also be problems $w$ ith equipment functioning $i r$ a reduced pressure environment. From strictly a cost standpoint, however, this alternative should exhlbit a misimal impact of perhaps only a few million dollars per plant.

\section{Double Containment}

Double containment, as envisioned in this study, would require the construction of another containment wall inside the existing containment structure. This passive system would be expected to require minimal reconfiguration of the plant layout but would probably necessitate a major redenlen of the contalnment and the equipment layout thereln. The smaller contalnment volume may 


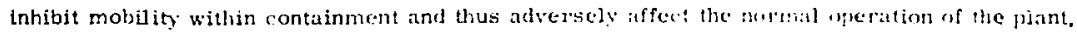

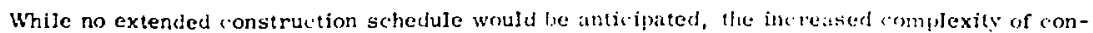
struction of the double wall and emplacement of the structures therein sould adel signjicantly to the cost of construction. It was estimated that this alternative could be implemented at a modest cost of perhaps $\$ 20-\$ 30$ million.

\section{Thinned 13ase Mat}

The thinned base mat altemative wruld frotribl, ast less than any of the alternatives con-

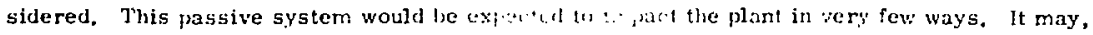
in fact. cost less to construct than curron, pla. $\therefore$. I w w ortainment foundation design would be necessary but this appears to be the only signiti at: urlverse impact of this alternative. Implementation of this alternative would be expected to tontilil minimal increased cost, perhaps a few million dollars.

Table XXI summirizes the results of the inpact portion of this study. l'iltered atmospheric venting, evacuated contaimment, and thinning the base mat would appear to be the least costly alternatives. The underground siting alternatives, both shallow and deep, would cntitil the most significant cost impacts primarily duc to anticipated construction schedule extensions associated with these altematives. 


\section{TABLE XXI}

Potential Impacts of Alternate Designs

\begin{tabular}{|c|c|c|c|c|c|c|c|c|c|}
\hline & $\begin{array}{c}\begin{array}{c}\text { Increased } \\
\text { Construction } \\
\text { Cost }\end{array} \\
\end{array}$ & 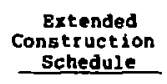 & $\begin{array}{l}\text { Significant } \\
\text { Regulatory } \\
\text { Delay } \\
\end{array}$ & $\begin{array}{c}\text { Active } \\
\text { Components }\end{array}$ & $\begin{array}{c}\begin{array}{c}\text { Significant } \\
\text { Design } \\
\text { Modifications }\end{array} \\
\end{array}$ & $\begin{array}{l}\text { Potential } \\
\text { Technological } \\
\text { Developments }\end{array}$ & $\begin{array}{c}\text { Impact } \\
\text { Normal } \\
\text { Operations }\end{array}$ & $\begin{array}{c}\begin{array}{c}\text { Potential } \\
\text { Multiple } \\
\text { Use }\end{array} \\
\end{array}$ & $\begin{array}{c}\text { Cost } \\
\text { Estigate } \\
\left(10^{6} \text { s) }\right.\end{array}$ \\
\hline $\begin{array}{l}\text { Filtered } \\
\text { Atuospher ic } \\
\text { Venting }\end{array}$ & $x$ & & & $\mathrm{x}$ & & & & $x$ & $0-10$ \\
\hline $\begin{array}{l}\text { Compar twent } \\
\text { Venting }\end{array}$ & $\mathrm{x}$ & Possidiy & & $\mathbf{x}$ & & & & $x$ & $20-10$ \\
\hline $\begin{array}{l}\text { Deep } \\
\text { Onderground } \\
\text { siting }\end{array}$ & $\mathrm{x}$ & $x$ & $x$ & $\mathrm{x}$ & $x$ & $x$ & $\mathrm{x}$ & & $200-100$ \\
\hline $\begin{array}{l}\text { Stronger } \\
\text { Conteinwent }\end{array}$ & $\mathbf{x}$ & & & & Some & & & & $15-25$ \\
\hline $\begin{array}{l}\text { Increased } \\
\text { Conteinament } \\
\text { Volune }\end{array}$ & $x$ & & & & Some & & & & $20-30$ \\
\hline $\begin{array}{l}\text { Shallow } \\
\text { Underground } \\
\text { siting }\end{array}$ & $\mathbf{x}$ & $x$ & $x$ & & $\mathrm{x}$ & & $x$ & & $100-200$ \\
\hline $\begin{array}{l}\text { Evacuated } \\
\text { Contalnuent }\end{array}$ & $\mathrm{x}$ & & & $\mathrm{x}$ & & & $x$ & & $0-10$ \\
\hline $\begin{array}{l}\text { Double } \\
\text { Conteineent }\end{array}$ & $x$ & & & & $x$ & & $x$ & & $20-30$ \\
\hline $\begin{array}{l}\text { Thinned } \\
\text { Base Het }\end{array}$ & & & & & $x$ & & & & $0-10$ \\
\hline
\end{tabular}




\section{CHAPTER VII. CONCLUSIONS}

The results of this study are presented in the form of a qualitative value-impact matrix shown in Figure 14. From this matrix it is apparent that, among the alternatives considered, filtered atmospheric venting offers the greatest potential for reducing public risk for the least impact. Compartment venting and deep underground siting offer similar potential for reducing public risk but greater impacts. Evacuated containment and thinned base mat, while being low impaet alternatives, offer little potential for reducing public risk. Combinations of alternatives were not considered. Each alternative was evaluated on its own merits rather than attempting to idenfity an optimal design combination.

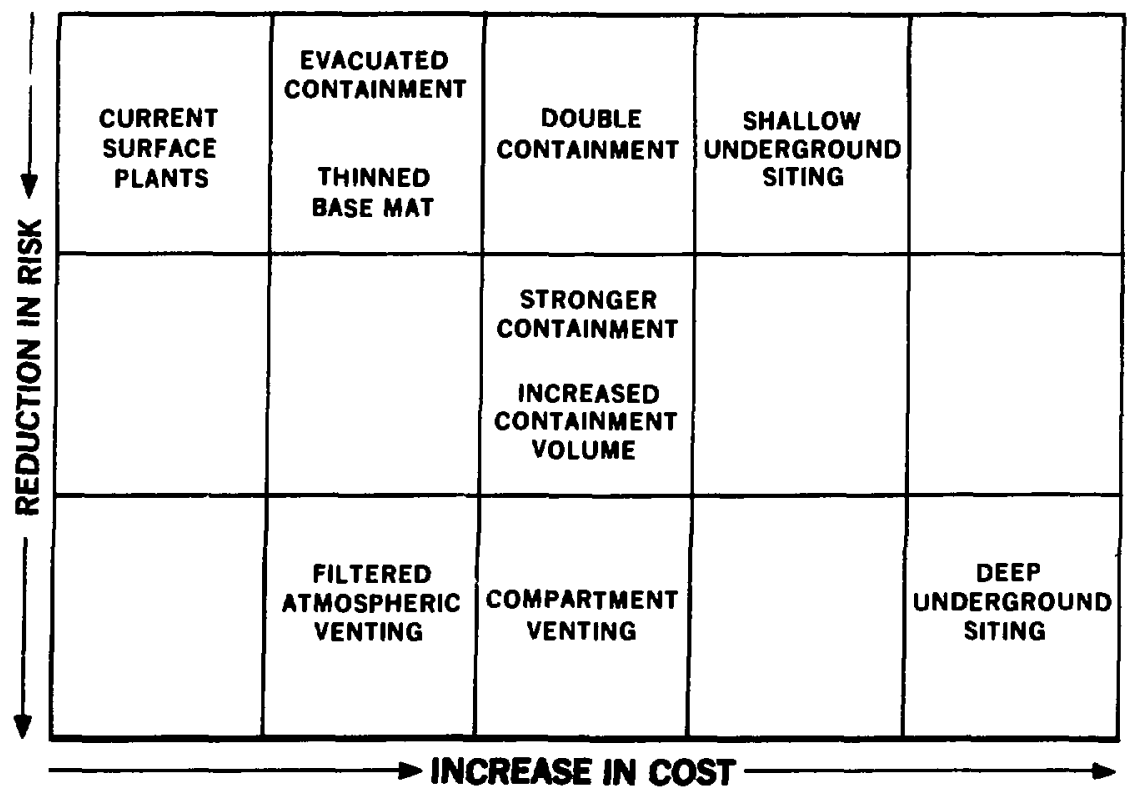

Figure 14. Qualitative Value-Impact Matrix

To place these regults in proper perspective, several points need to be made. These results are based primarlly on rlek ingights from WASH-1400 which considered only two reactors, Although efforts have been made to eliminate atyplcal characteristics of these plants, the results of this study hould be treated only as indicative of what might be found in a broader study. The baglc 
premise that overpressure failures dominate risk should, however, be true in general. Although care was taken to define feasible reference designs, the scope of the study did not allow detailed feasibility studies, Before a decision to implement any of these alternatives, detailed studies are recommended of the particular alternatives considered.

The risk reductions presented should be regarded only as potential risk reductions. Eliminating some of these containment failure modes may reduce the probabilities such that other factors, previously determined to be insignificant risk contributors in the Reactor Safety Study and thus not studied in detail, now may become more important and, perhaps, could dominate the risk. Finally, the broader question of whether any alternate containment design to reduce public risk is justified was not addressed. If however, alternate containment designs are seriously considered, it is believed that this study identifies those design alternatives which would most merit further attention. 